Article

\title{
Sustainable Value Chain of Industrial Biocomposite Consumption: Influence of COVID-19 and Consumer Behavior
}

\author{
Didzis Rutitis ${ }^{1,2, *(\mathbb{D})}$, Anete Smoca ${ }^{3}$, Inga Uvarova ${ }^{2,4}\left(\mathbb{D}\right.$, Janis Brizga ${ }^{1,5}(\mathbb{D}$, Dzintra Atstaja $2,6, *(\mathbb{D})$ \\ and Inese Mavlutova $7, *$ (D)
}

1 Circular Economy Center, Liepaja University, Lielā st. 14, LV-3401 Liepaja, Latvia; janis@zalabriviba.lv

2 Management Department, BA School of Business and Finance, K.Valdemara st. 161, LV-1013 Riga, Latvia; inga.uvarova@gmail.com

3 Institute of Design Technologies, Faculty of Materials Science and Applied Chemistry, Riga Technical University, Kipsalas st. 6, LV-1048 Riga, Latvia; anete.smoca@rtu.lv

4 ArtSmart, Vidrižu st. 1c-29, LV-1006 Riga, Latvia

5 Department of Geography and Earth Sciences, University of Latvia, Jelgavas st. 1, LV-1004 Riga, Latvia

6 Legal Department, Faculty of Law, Riga Stradins University, Dzirciema st. 16, LV-1007 Riga, Latvia

7 Department of Economics and Finance, BA School of Business and Finance, K.Valdemara st. 161, LV-1013 Riga, Latvia

* Correspondence: didzis.rutitis@ba.lv (D.R.); dzintra.atstaja@ba.lv (D.A.); inese.mavlutova@ba.lv (I.M.)

check for updates

Citation: Rutitis, D.; Smoca, A.;

Uvarova, I.; Brizga, J.; Atstaja, D.; Mavlutova, I. Sustainable Value Chain of Industrial Biocomposite Consumption: Influence of COVID-19 and Consumer Behavior. Energies 2022, 15, 466. https:// doi.org/10.3390/en15020466

Academic Editor: Manuela Tvaronavičienè

Received: 8 December 2021

Accepted: 5 January 2022

Published: 10 January 2022

Publisher's Note: MDPI stays neutral with regard to jurisdictional claims in published maps and institutional affiliations.

Copyright: (C) 2022 by the authors. Licensee MDPI, Basel, Switzerland. This article is an open access article distributed under the terms and conditions of the Creative Commons Attribution (CC BY) license (https:// creativecommons.org/licenses/by/ $4.0 /)$.

\begin{abstract}
The COVID-19 pandemic has been one of the most unprecedented crises of recent decades with a global effect on society and the economy. It has triggered changes in the behavior and consumption patterns of both final consumer and industrial consumers. The consumption patterns of industrial consumers are also influenced by changes in consumer values, environmental regulations, and technological developments. One of the technological highlights of the last decade is biocomposite materials being increasingly used by the packaging industry. The pandemic has highlighted the problems and challenges of the development of biocomposites to adapt to new market conditions. This study aims to investigate the industrial consumption of biocomposite materials and the influence of the COVID-19 pandemic on the main stages of the value chain of sustainable industrial consumption of biocomposites. The research results reveal there is a growing interest in the use of biocomposites. Suppliers and processors of raw materials are being encouraged to optimize and adapt cleaner production processes in the sustainable transition pathway. The study highlights the positive impact of COVID-19 on the feedstock production, raw material processing, and packaging manufacturing stages of the value chain as well as the neutral impact on the product manufacturing stage and negative impact on the retail stage. The companies willing to move toward the sustainable industrial chain have to incorporate economic, environmental, social, stakeholder, volunteer, resilience, and long-term directions within their strategies.
\end{abstract}

Keywords: sustainable industrial consumption; sustainable value chain; biocomposite; sustainable packaging; COVID-19 pandemic influence; consumer behavior

\section{Introduction}

The Sustainable Development Goals (SDG) of the United Nations (UN) provides a global road map of seventeen objectives promising access to sustainable development, and SDG12 in particular is devoted to the promotion of sustainable consumption and production [1]. According to the UN (2021), the material footprint has significantly increased (by $70 \%$ ) since the year 2000, highlighting threats of a sharp increase in the use of plastic bags and bottles and a comparatively small amount of plastic and electronic waste recycled. The scientific community confirms the importance of SDGs in addressing economic, social, and environmental issues that plague the world and promotes the concept of sustainability [2]. 
However, the implementation framework of SDGs is criticized by researchers and practitioners due to the lack of clear and sound practical tools for the sustainable transition and change toward sustainable consumption [3].

The circular economy advocates sustainable development, promoting the necessity to strike a balance between environmental and economic values. In turn, this leads to the need for solutions that help businesses ensure both a positive impact on the environment and insufficient financial returns on profit and investments $[4,5]$.

While climate change remains one of the biggest global challenges, the current COVID-19 pandemic also highlights environmental and climate challenges. Achieving zero greenhouse gas emissions requires economic and social change. The packaging industry as one of the biggest contributors to the greenhouse effects is one of the first to be forced to respond to the goals of the European green transition, which envisages the implementation of an industrial policy for the circular economy [6], and the UN Sustainable Development Goals [1]. Several of the European Union leading retailers are committed to a full transition toward circular economy business models, including the use of $100 \%$ recycled or other sustainably sourced materials by 2030 [7].

The growing variety of environmental restrictions and requirements of policymakers is a catalyst for an increase in the demand for renewable and biodegradable composite materials. Recent advances in the availability of biodegradable polymers and the focus on the use of natural fibers have offered opportunities to produce highly durable biodegradable polymer composite systems [8]. During the COVID-19 crisis, consumers have also taken the lead in forcing industries to change and invest in innovations that facilitate the reduction of the environmental footprint [9].

With the overall increase in consumption stimulated with more sophisticated applications and products introduced within the market, the market for bioplastics is continuously growing and diversifying. The global production capacity of bioplastics is set to increase from around 2.11 million tons in 2020 to approximately 2.87 million tons in 2025 . The production capacity of biodegradable plastics is increasing due to the availability of new types of raw materials [10].

There are several important arguments for the manufacturers encouraging improvements, which already have been substantiated in previous studies:

- Public and customer requirements [11] for sustainable and especially environmentally friendly solutions derived by regulations and quality management standards [12].

- Opportunity to stand out in the industry with innovations triggered by the adoption of environmental requirements asserted by the Porter hypothesis [13,14].

- Strategic goals and the motivation of companies to increase competitiveness and value by ensuring environmentally responsible and sustainable performance [15-17].

- Opportunities for the development of new sustainable business models and creation of revenue streams [18]

- Corporate social responsibility (CSR) program and the sustainability performance $[19,20]$.

- Sustainable positioning of the company $[20,21]$ and the green branding $[22,23]$ as unique sales offers in the industry based on the product declaration or the Life Cycle Analysis (LCA) to avoid the "greenwashing" practice [24-27].

Unless the introduction of sustainable packaging has been shown to drive sales or reduce costs, companies, despite promoting their sustainability intentions, lack the business opportunity to pursue more sustainable packaging.

The circular economy emphasizes the importance of reuse and recycle principles rather than extracting natural resources. This means that previously used materials should be recovered and reused in different ways, thereby securing natural resources from overexploitation [28]. In turn, this requires the development of innovative technologies that allow the recovery of valuable materials [29].

At present, much more than before, the new sustainability transition has escalated the necessity of companies and their supply chains to reconsider the contribution to three important values-environmental, social, and economic: the so-called triple bottom line [30]. 
In the context of sustainable development, there is great potential for the cultivation and processing of durable natural fibers into new products. The demand for such products is increasing due to the growth of the level of education and well-being in developed countries [31].

Packaging has a major influence on sustainable consumption. The packaging value chain covers various industries and different actors in each stage of the value chain [32] (see Figure 1). The sustainable consumption value chain in this conceptual model consists of five main stages. The first stage in the value chain is Feedstock production \& pre-treatment, which is represented by the source of the raw material: the farmer who is the supplier and processor of the raw material. This is followed by the Raw material processing and refining phase, which is represented by downstream processors of the raw material, who offer their processed products in several sectors. Packaging manufacturing is the stage where, using various technologies, the shape of the packaging is obtained and its characteristics are defined for further use. The product manufacturer uses this packaging to package its products as set out in its sustainable packaging strategy. The Retailer stage is represented by leading retailers of food, cosmetics, clothing, accessories, and other consumable products.

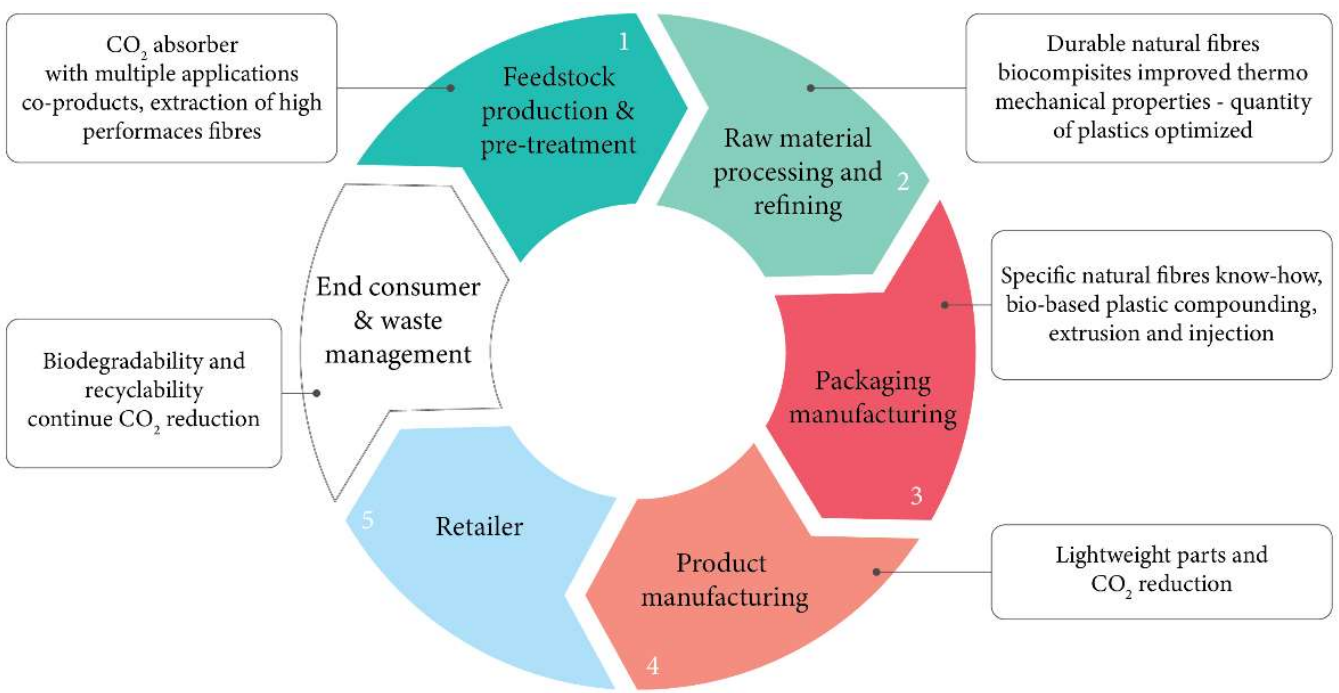

Figure 1. The conceptual model of the value chain of sustainable industrial consumption and related benefits from biocomposites (source: the authors).

This study has a particular focus on the investigation of sustainable preferences, consumption patterns, and derived challenges within the business-to-business (B2B) segment, namely, the industrial customers. Yet, the academic community has paid more attention to the sustainable consumption practices in the business-to-customer (B2C) segment expanding the scientific discourse on the consumption of individuals, their motivation factors to make pro-environmental and sustainable purchase decisions, while the sustainable industrial consumption is less studied [33]. This is strongly influenced by beliefs and the pro-environmental mindset of managers and owners of companies and their industrial partners [34].

This study aims to investigate the industrial consumption of biocomposite materials and the influence of the COVID-19 pandemic on the main stages of the value chain of sustainable industrial consumption of biocomposites. This research has a particular focus on the industrial stakeholders in the value chain until packaging reaches the end consumer. Thus, the end consumers and the waste management aspects have not been covered by this research, forming limitations and an avenue for future research.

This research contributes to the theory and practice regarding the enablers and challenges for the use of biocomposites in the further transformation toward more sustainable consumption. This study highlights the research gaps that still need to be investigated regarding the impact of COVID-19 on the sustainable consumption of end consumers 
and their changing behaviors that confront the traditional less sustainable practices of industrial consumers.

The paper is organized in the following sections: the second section provides an analysis of the literature. The third section explains the methodological approach and research methods applied within this study. The fourth section reveals the results of the exploratory research. The fifth section represents the interpretations of the main issues discussed and summarizes the implications stated. In addition, the conclusions, limitations, and the future research agenda are summarized in the last section of this article.

\section{Literature Review}

First, a comprehensive and non-systematic literature search was performed with Google Scholar to identify the most appropriate keywords and phrases in order to select the most appropriate literature and conduct a more accurate literature review. Based on the initial literature search and key concepts identified, we selected peer-reviewed articles from the SCOPUS database in order to conduct an in-depth literature review. In order to widen views and deepen the theoretical analyses, we purposefully added additional scientific articles (e.g., from Ebsco, Emerald databases, and other sources referenced by other researchers) [35-37].

Based on an in-depth literature review, this paper explores the related concepts of sustainable industrial consumption and the role of biocomposites within this area. The literature analysis provided an investigation of the overall insight and deeper artifacts from the academic debates into the relevant topics under investigation [38,39].

\subsection{Sustainable Industrial Consumption}

Within the literature review, publications were selected from the SCOPUS database using the keywords "sustainable consumption", with a particular focus on the business to business (B2B) or the industrial relationship. In total, 1238 publications were selected from the SCOPUS database using the following keywords: TITLE-ABS-KEY ("sustainable consumption") AND ("B2B" OR "Industrial"). A chronological analysis of the most common words was performed using VOSviewer grouping these keywords within clusters of interrelated keywords (Figure 2). At the beginning of the last decade, the research paid more attention to ensuring environmentally-friendly manufacturing [12,40-42], material flow [43-45], and resource efficiency [46-48] with its impact on the environment and climate change. The energy and natural resources were of particular interest [47,48]. The most common empirical research methods applied by the academic community are the input-output analysis [49], life cycle analysis [50], and statistical modeling of scenarios related to the footprint $[51,52]$.

While in the previous decade, there was a significant interest in this field among environmental and engineering researchers, the scientific debate within the social sciences has been intensifying in the last 5 years in such disciplines as entrepreneurship, innovation, management, and marketing [53-55]. The academic community has widened investigation subjects to the adoption of practical tools and methods encouraging sustainable industrial consumption within organizations [56-58]. More importantly than before, researchers explore waste management from the perspectives of its recycling or use as a valuable resource for creating new products and the added value for the customer, shareholders of ventures, other stakeholders, and wider society [59-61]. Recently introduced research topics cover the sustainable value chain, new sustainable business models, the creation and delivery of sustainable value, and changes in the consumption patterns to more sustainable consumer behavior [54,62-64].

The most important trends within the scientific literature show that the term "sustainable consumption" appeared at the end of the last century, and its popularity has grown moderately over time. The dynamics can be linked to different political and historical events. In a broader sense, researchers link sustainable consumption with more specific patterns and habits for purchasing and consuming goods $[65,66]$ or an introduction of 
the product service systems [67] or the sharing [68,69]. Armstrong [70] exploits the term "mindful consumption" where mindfulness strongly reflects the spiritual consciousness and higher moral values of consumers that lead to sustainable and pro-environmental purchase decisions.

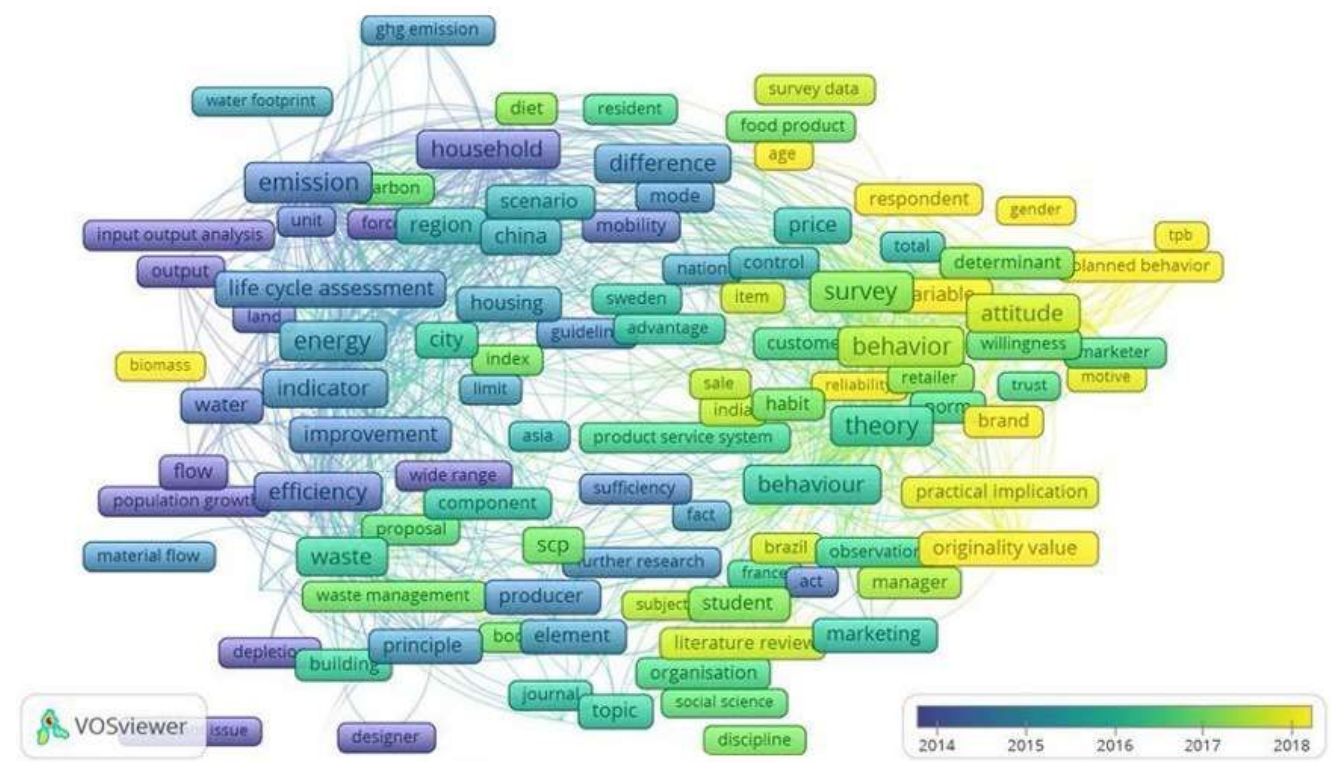

Figure 2. The overlay visualization of co-occurrence of keywords "sustainable consumption", "B2B", or "Industrial" based on the SCOPUS articles, which was created by the authors using VOSviewer (version 1.6.17).

Researchers consider that consumer behavior has a strong impact on the environment through consumer choices of products and services [71]. The scientific debate shows a consensus that sustainable consumption positively impacts the environment, reduces footprints, and contributes to the transition from a linear to a circular economy [72]. Researchers mostly analyze sustainable consumption within specific sectors or product groups, such as food, textiles, clothing, plastics, and energy [72-75].

Studies more often associate sustainable consumption with the consumption of individuals or households $[65,66,76]$ but less with the industrial supplies into the businessto-business (B2B) segment, proving the existing gap within this scientific domain. The research on the consumption of industrial customers often leads to a discussion about the sustainable value chain or the sustainable supply chain. The term "value chain", which entered the colloquial language in the 1980s, experienced a surprisingly rapid rise in the mid-1990s and a real breakthrough at the turn of the century.

Scholars highlight the importance of industrial symbioses in the promotion of sustainable consumption to industrial customers [77]. Researchers are also seeking new business models and forms of collaboration that promote greener consumption, such as the sharing of resources or assets [78], product-service systems [67,79], online shopping, and digital services and platforms [80].

In total, 580 articles were selected within the SCOPUS database using keywords "sustainable supply chain" and "value chain" (TITLE-ABS-KEY ("sustainable supply chain") AND ("value chain")). The chronological frequency and interconnection of keywords were analyzed by VOSviewer, and the visualization of results highlights the main clusters of keywords (Figure 3). Porter [81] has laid an important foundation in the study of the value chain, explaining the stages of the value chain and their role in the development of the competitiveness and other economic factors of companies. While Porter describes the value chain within the firm or an industry level, Koval et al. [82] emphasize the economic relationships between the companies on the global scale of the value chain. The global and cross-sectoral economic relationships within the value chain are important factors in addressing the climate change and environmental threats [82]. The technological feasibility 
and economic interests of stakeholders are predominant factors to increase the value and achieve the competitive advantage. In a sustainable value chain, these factors must be balanced with environmental values. Accordingly, these factors often prevail as constraints for companies to develop a sustainable value chain, but they should be major within the sustainability policies [83].

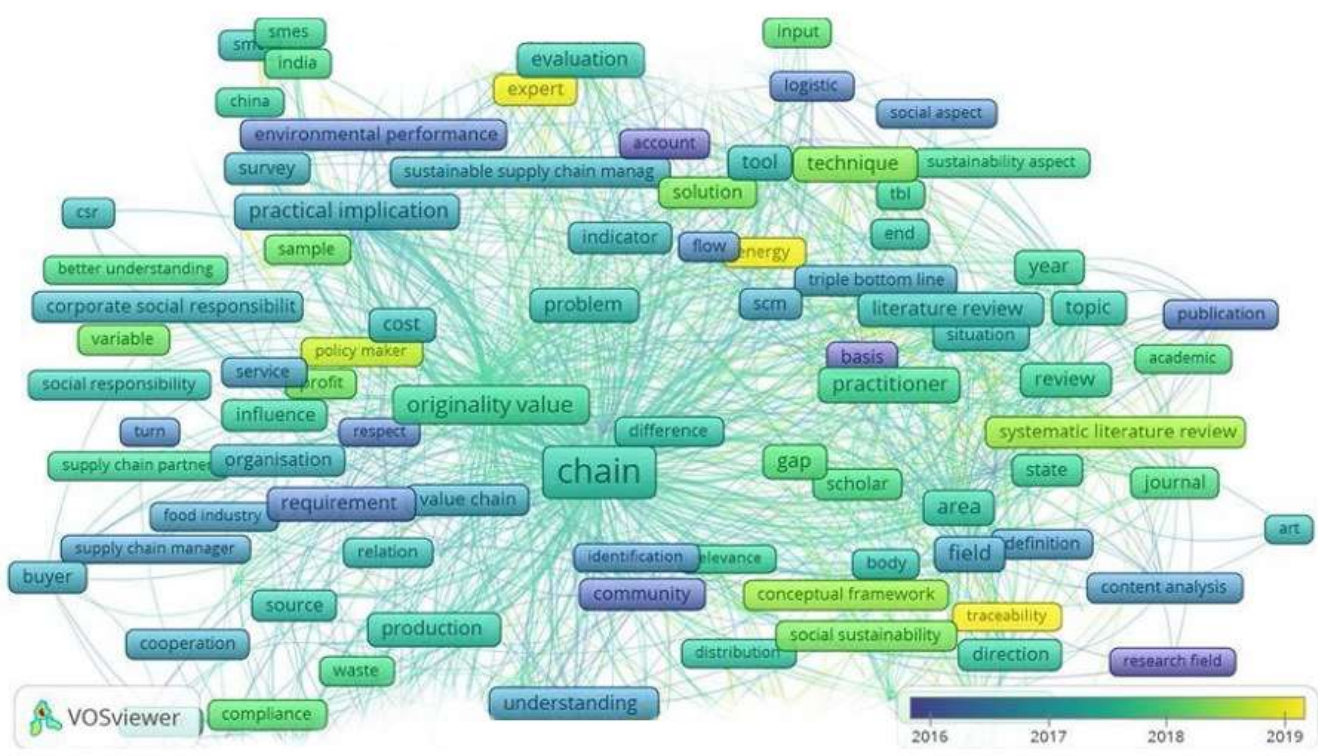

Figure 3. The overlay visualization of co-occurrence of keywords "sustainable supply chain" and "value chain" based on the SCOPUS articles, which was created by the authors using VOSviewer (version 1.6.17).

The chronological application of keywords reveals that in the middle of the last decade on sustainability issues in the context of supply chains, academic discussions were focused on environmental requirements as well as the footprint and the environmental performance of the manufacturers [37,84-86]. The food industry has been of large interest to researchers $[85,87]$. Moreover, geographically, the issues of India and China are most often discussed and reflected in the research. In recent years, sustainability issues have become increasingly important and analyzed in a much broader context $[85,88]$.

Seuring and Müller [37] emphasized that the sustainable value chain envisages the integration of environmental and social principles in addition to the economically rational purchase and supply decisions; although often, the motivation to integrate environmental and social principles is derived from specific standards (e.g., ISO, TEQM) or government regulations. These researchers proposed the necessity of more transparent collaboration between the sustainable supply chain actors, allowing for the possibility to track and evaluate the performance, risks, and the clean, green, and lean aspects of production of raw materials [37].

Researchers Ahi and Searcy [89] argue that the sustainable supply chain means having a greater focus and coordination over the materials or product flows, encountering the involved stakeholders in a closer relationship, as well as keeping a strong streamline on the value, efficiency, and performance. Thus, the sustainable supply chain requires the management of the flows of materials, resources, finances, and information, paying specific attention to engagement with collaborative networks as well as the economic value and also the creation of environment and social values, thus leading to more satisfied customers. Ahi and Searcy [89] highlight that the sustainable value chain incorporates the economic, environmental, social, stakeholder, volunteer, resilience, and long-term strategies or business directions. These are not just declarative statements but important issues that should be observed and adopted in any organization belonging to the sustainable supply chain [89]. 


\subsection{The Sustainable Industrial Consumption of Biocomposite Materials}

Ngram Viewer allows conducting the content analyses by tracing the frequency of the selected concepts and keywords (plastic waste, biocomposite, microplastic) during the specified time period (since the year 2000). Ngram Viewer digitalized how often these selected terms or concepts appear in digitalized texts of the literature accumulated within Google, in particular, Google Books [90].

Accordingly, the analytical information of Ngram Viewer demonstrates that the topicality of the term "biocomposite" has been dynamic since the late 1970s until the turn of the century, then showing a rapid increase, especially from 2013. For comparison, studies on "plastic waste" have been investigated since the middle of the last century. It should be highlighted that, simultaneously with the rapid rise of the use of the term "microplastic", the curve of "biocomposite" also increases in parallel.

The use of all three researched concepts has grown rapidly over the last ten years (see Figure 4). This justifies the wider applicability of these terms in the theoretical or scientific literature and other sources used by practitioners. In the figure, the horizontal axis indicates the specific time period, while the vertical axis shows the rate of the occurrence of that particular concept or keyword from all search strings (so called n-grams) in a particular year [90].

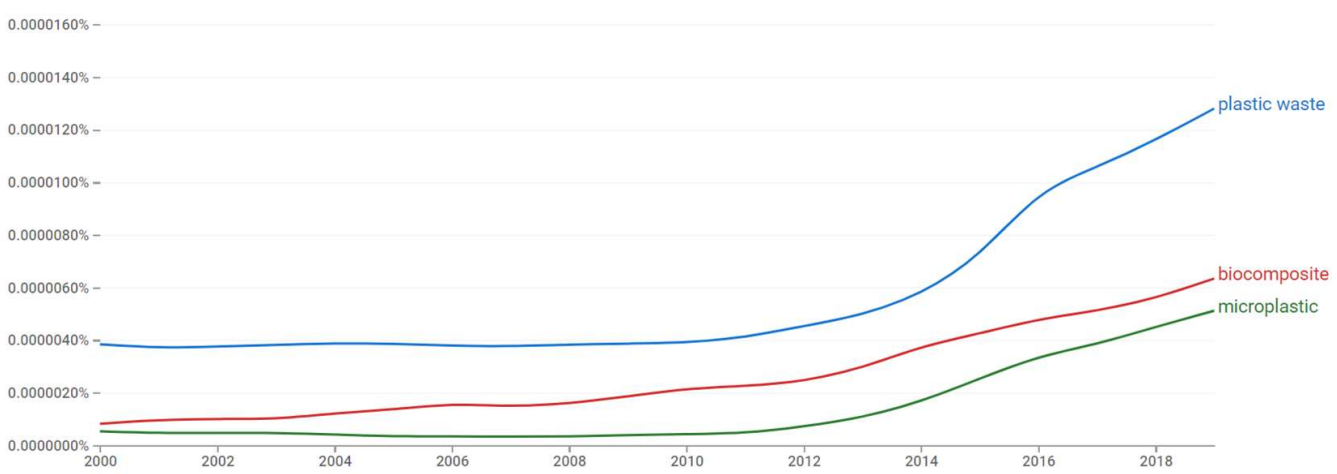

Figure 4. The frequency of using keywords "biocomposite", "plastic waste", and "microplastic", which was created by the authors with Ngram Viewer.

The analytical results of the Ngram Viewer screening verify and confirm the relevance and significance of selected concepts and keywords for the further in-depth literature review. Given that "what makes the Ngram Viewer a valuable research tool is not primarily its accuracy, but rather its potential for quick-and-dirty heuristic analysis" ([90], p. 9), this illustrates the dynamic changes and trends on the interest of particular terms, keywords, and concepts.

The creation of a model of sustainable industrial consumption that would help reduce the environmental problems associated with conventional plastics, including microplastic pollution in habitats, still seems a utopian idea in the near future, given that conventional plastics (polypropylene-PP, polyethylene terephthalate-PET, high-density polyethyleneHDPE, etc.) play a key role in the economy [91].

While the world is struggling with the recycling of conventional plastics, another way to respond to this problem would be to develop and use bio-based or biodegradable plastics as a sustainable alternative to petroleum-based plastics [92]. These materials mainly help to preserve fossil reserves by replacing fossil carbon. They also provide additional benefits: biocompatibility, biodegradation, and carbon dioxide $\left(\mathrm{CO}_{2}\right)$ sequestration, which are important for reducing global warming [93].

It is important to emphasize that the terms "bio-based plastic" and "biodegradable plastic", which are often used in the scientific literature, are fundamentally different. Biodegradable polymers are materials that are capable of degrading when subjected to aerobic, anaerobic, or microbial processes. Biodegradability can be defined as the ability of compounds to degrade completely under the influence of various factors, including the 
size, thickness, and composition of the material. However, it should be stressed that biobased plastics are produced from renewable sources and can be either biodegradable (e.g., polymerized starch or polylactide) or non-biodegradable (e.g., bio-polyethylene), which is a significant part of the environmental impact assessment. It should also be mentioned that bio-polyethylene is only recyclable for a few cycles until it significantly loses its original properties [94,95].

Many initiatives have been introduced to promote the concept of sustainable packaging. The Sustainable Packaging Coalition (SPC) in 2011 formulated the industry-accepted definition of seven conditions specifying the following seven criteria for sustainable packaging [96]:

- Beneficial, safe, and healthy for all individuals and communities throughout their life cycle;

- Meets market criteria for performance and costs;

- $\quad$ Obtained, produced, transported, and processed using renewable energy;

- Produced using renewable or recycled raw materials and clean production technologies;

- Made of harmless materials in all possible end-of-life scenarios;

- Designed to optimize used materials and energy consumption;

- Recovered and utilized in industrial and/or biological cradle-to-cradle or closed-loop cycles.

The SPC definition is widely recognized and includes the functional, environmental, and technological dimensions of sustainable packaging. Therefore, sustainable packaging may protect the product and communicate its properties, including reusing materials and reducing waste throughout the packaging life cycle from production to consumption, as well as during the disposal and post-disposal phases [97,98].

Sustainable packaging has to be designed with innovative bio-based plastic packaging materials and meet the following parameters:

- The materials must be optimized to improve the shelf life of the product;

- The packaging should be intended for recycling;

- Bio-based materials should be efficiently produced from the second-generation feedstock.

Monoplastic materials are preferred because the recycling of such packaging material preserves functional properties and chemical safety. The sum of the climate and environmental impacts of packaging/food systems should be assessed throughout their life cycle and reduced to the chosen design $[99,100]$.

Designing a more sustainable food packaging is a difficult task, as many different parameters need to be considered. Life Cycle Assessment (LCA) tools are available and should be used to quantify and compare the environmental impact of different types of packaging, considering the overall product framework. LCA should be able to make informed and holistic decisions about how to improve the sustainability of food packaging $[50,100]$.

Some of the factors hindering the introduction of more sustainable packaging solutions on the market are consumer awareness of unknown technologies, costs, regulatory issues, and the belief that sustainable packaging fails to protect food (e.g., moisture barriers) [100].

With the introduction of the concept of sustainable development, there is also a rapidly growing interest in the use of biodegradable polymers in the production of new composite materials [101,102]. One of the fastest-growing industries is polylactic acid, which differs from the commonly available form of thermoplastic polymers. It is mainly derived from renewable resources such as maize starch or sugar cane [103].

Recently, during the COVID-19 pandemic, consumers showed an increased desire for their personal safety and health $[104,105]$. This affects the safety standards and requirements for packaging materials, and in addition to the flexibility or rigidity, the durability or physical integrity of materials; thus, there is a growing interest in the use of sustainable and natural materials $[8,106,107]$. It means that at the same time, while considering the possibilities to adopt sustainability characteristics, the packaging materials must provide adequate 
isolation properties against water vapor, gases, odors, and other protection against various external factors. Polylactic acid (PLA) is one of the most recognized biodegradable materials [108], which is not only used in the food industry but also in the biomedical and pharmaceutical industries [109,110]. As reported by Cohn et al. [111], PLA is recognized as safe for use in the food contact. Nevertheless, the final properties of PLAs may vary and depend on their chemical-physical, barrier, thermal, and mechanical properties. These properties can be adapted to the intended use by altering the structure of the PLA (amorphous and crystalline ratio, different meso-lactide ratio, and molecular weight) [108].

Previous research $[8,107,108]$ proved that biodegradable polymers are promising and potentially in-demand materials not in the near future but already in the reality of today's packaging and delivery systems. However, there is still a scope to explore ways for improving the applicability of these materials, both in terms of their characteristics of the technical feasibility and in terms of their desirability and cost-effectiveness to use them by various industries. The main advantage of biocomposite materials is found not only in their natural origin but also in providing a closed circle "from nature to nature" as these materls decompose into the naturally occurring components.

\subsection{Role of Biocomposites in Industrial Consumption}

In order to conduct further in-depth literature analysis, in total, 1361 articles were selected within the SCOPUS database using keywords "biocomposite" and "biopolymers". The interconnection of keywords was analyzed by VOSviewer, and the visualization of results highlights the main clusters or concepts explored most often in the previous studies. The following picture demonstrates the chronological frequency and interlinkage of the keywords applied in the research (Figure 5).

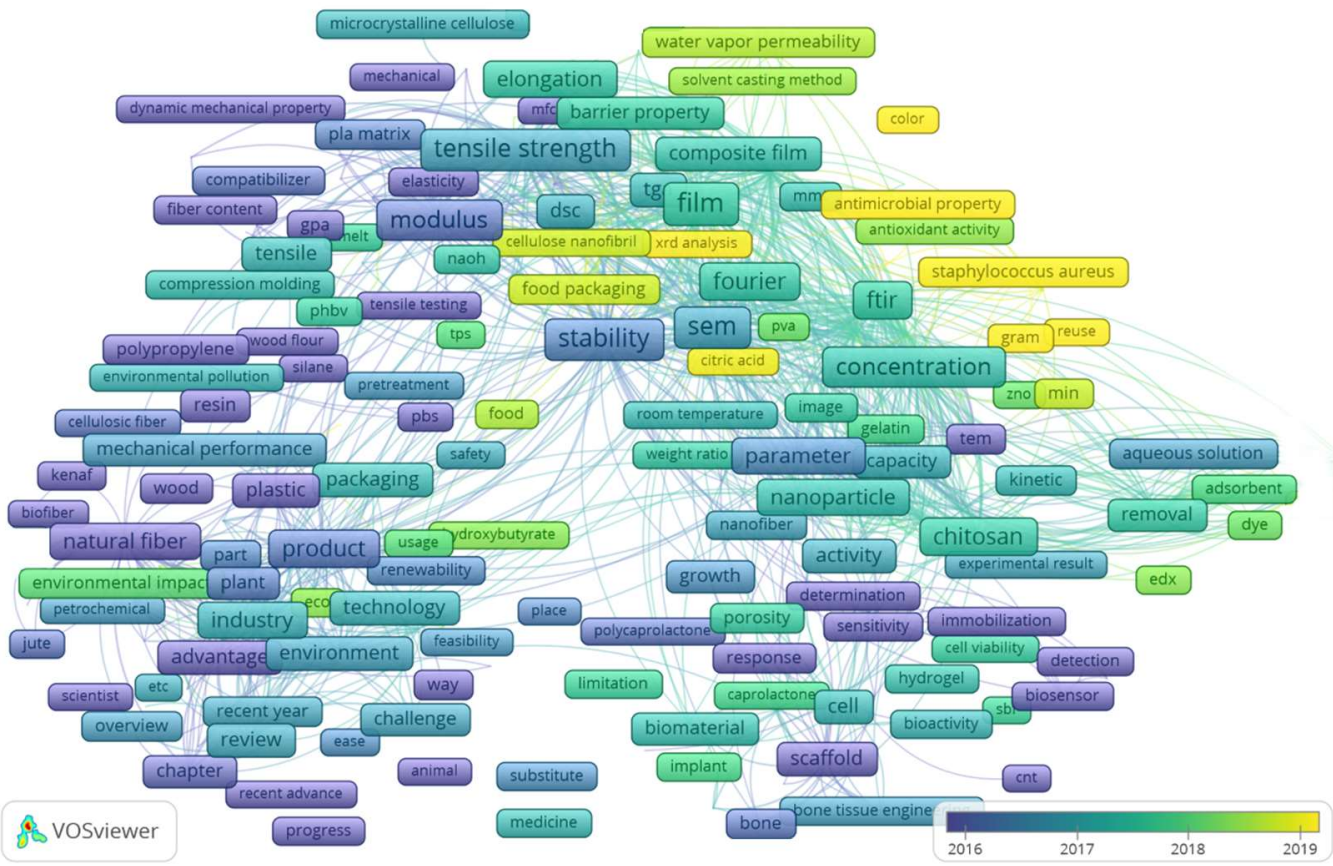

Figure 5. The overlay visualization of co-occurrence of keywords "biocomposite" and "biopolymer" based on the SCOPUS articles, which was created by the authors using VOSviewer (version 1.6.17).

Industrial production based on non-renewable resources, a growing demand for end products, a rapidly growing population, and density are all placing an increasing burden on the resources, and all types of pollution are proliferating at an alarming rate. Consequently, more and more attention is being paid to sustainable economic development by using new natural materials. High hopes are placed on the development of composites reinforced with natural fibers and the versatile use of materials based on non-renewable raw materials [102]. 
The non-degradable nature of conventional plastic waste in ecosystems has increased consumer interest and scientific research into more environmentally friendly bio-based plastic materials and biocomposites [111]. Due to the advantages of recyclability, lightness, and cost-effectiveness, biocomposites are of interest to researchers in the field [111-114]. Biocomposite constituents such as bio-based polymers and fillers are obtained from renewable natural sources and can serve as a possible replacement for oil-based non-renewable plastics [115]. Biocomposites are reasonably less likely to have an impact on the environment and therefore are considered safer for both human and other living habitats. In addition, most of them are recyclable and reusable. One of the most important benefits of biocomposites is that these materials have a manageable potential at the end of disposal [116]. Biocomposite raw materials are divided into two groups: the first group of raw materials is wood (their use in larger quantities can lead to deforestation and affect biodiversity), while the second group of raw materials is lignocellulosic waste or production by-products collected from food, forest, and agricultural residues. Until now, the second group of by-products has been used for the development of biocomposites, although their commercialization is still limited. Extensive research in the field of biocomposites has led to the development of various types of biocomposites [117].

The role of the reinforcement phase in biocomposite material is to increase the mechanical properties of the polymer matrix system, with different reinforcements having different properties, thus influencing the composite properties in different ways [118]. The need to improve and stimulate rural economies as well as reduce the world's dependency on petroleum-based materials has resulted in much interest and focus on the use of various varieties of natural fibers as reinforcing agents for composite materials [119]. The high strength, availability, low cost, sustainability, and eco-friendly characteristics of natural materials such as agricultural waste make them quite beneficial and efficient as reinforcement for composite materials [120]. Other advantages of natural fibers over synthetic fibers include their acceptable specific properties, ease of separation, and enhanced energy recovery. These advantages of natural fibers (flax, hemp, kenaf, henequen, banana, oil palm, and jute) over synthetic fibers have given lignocellulosic fiber substitutes huge potential for synthetic fibers. In contrast to synthetic fiber-based polymer composites, natural fiberbased composites can be disposed of easily or composted at the end-of-life stage without polluting the environment [121,122].

The commonly used natural feedstocks for biocomposites are flax, hemp, jute, and sisal (see Table 1). There is growing market interest in the use of hemp fiber for a variety of applications due to its quality, availability, and cost. Hemp is a sustainable multi-purpose crop, because it is possible to use all parts of the plant efficiently. Hemp-based materials are reusable, biodegradable, and/or compostable, which helps in achieving the goals of the EU Circular Economy Action Plan and initiatives to stimulate lead markets for climate-neutral and circular products in energy-intensive industrial sectors [10].

Hemp fibers are one of the most environmentally-friendly natural fibers with high tensile strength; they retain their strength in the wet state and other properties that make them suitable for a variety of industrial products. Therefore, hemp is one of the most promising sources of renewable resources to replace non-renewable components in a wide range of industrial products. From the point of view of the concept of sustainable development, the advantage of hemp fiber extraction is that it is possible to use all parts of the plant to produce different products at the same time-hemp seeds, their shells, hemp stalks, thus maximizing their added value. Combining natural fibers in the composite with a matrix derived from natural products succeeds in solving one of the most important problems of the century-preserving the viability of the environment [123].

The European Industrial Hemp Association [124] reported that hemp could allow us to capture and store significant amounts of $\mathrm{CO}_{2}$. One tonne of harvested hemp stem corresponds to 1.6 tonnes of $\mathrm{CO}_{2}$ absorption. Based on land use, using an average yield of 5.5 to $8 \mathrm{t} / \mathrm{ha}$, this is 9 to 13 tonnes of $\mathrm{CO}_{2}$ absorption per hectare harvested. Hemp cultivation requires little or no resources, and it has a positive impact on soil and biodiversity. As all 
parts of the plant can be used or further modified, its treatment does not generate waste. Beneficial effects can also be seen in future crops in this soil: studies have shown that wheat yields have increased by 10 to $20 \%$ since hemp cultivation [124].

Table 1. Property comparison of the commonly used fibers for biocomposites, created by authors based on [122].

\begin{tabular}{lllll}
\hline Fiber Type & Flax & Hemp & Jute & Sisal \\
\hline Density $\left(\mathrm{g} / \mathrm{cm}^{3}\right)$ & $1.4-1.5$ & $1.4-1.5$ & $1.3-1.5$ & $1.3-1.5$ \\
Tensile Strength $(\mathrm{Mpa})$ & $343-2000$ & $270-900$ & $320-800$ & $363-700$ \\
Tensile Modulus (Gpa) & $27.6-103$ & $23.5-90$ & $8-78$ & $9-38$ \\
Specific Modulus & 45 & 40 & 30 & 17 \\
Elongation to Break (\%) & $1.2-3.3$ & $1-3.5$ & $1-1.8$ & $2-7$ \\
Cellulose (wt \%) & $62-72$ & $68-74.4$ & $59-71.5$ & $60-78$ \\
Hemicellulose (wt \%) & $18.6-20.6$ & $15-22.4$ & $13.6-20.4$ & $10-14.2$ \\
Lignin (wt \%) & 2.3 & $3.7-10$ & $11.8-13$ & $8-14$ \\
Moisture content (wt \%) & $8-12$ & $6.2-12$ & $12.5-13.7$ & $10-22$ \\
Cost per weight (EUR/kg) & 8.0 & 1.1 & 0.3 & 0.9 \\
\hline
\end{tabular}

New composite materials are constantly being developed in the world, which envisages a wide range of applications. Biodegradable composite material from hemp fiber and polylactide or polymerized corn starch provides the necessary mechanical properties for a wide range of applications, and also the material development technology is suitable for products of various shapes and scales.

Biocomposites are innovative materials consisting of an environmentally friendly polymer matrix and reinforcing fibers and are currently an alternative to traditional composite materials. These materials have a wide range of applications. For biocomposites to be classified as biodegradable and green, they must comply with the principles of Green Chemistry, which is part of the concept of sustainability [125]. To integrate the SDG with biocomposites development and consider them sustainable materials, the acceptance of Green Chemistry principles plays a fundamental role [126,127]. Natural fiber-reinforced PLA biocomposites have potentially valuable properties such as their low density, low cost, and reduced solidity when compared with synthetic biocomposite products [108].

Biocomposites could be classified as bio-based only when both their constituents originate from natural resources. However, it is defined as a green material if the polymer matrix is derived from biomass or petroleum-based sources, and at the same time, the biocomposite is biodegradable [128]. Chemat et al. [128] reported that a relevant example of the petrochemically-derived green biocomposite is poly ( $\varepsilon$-caprolactone) (PCL), which is sourced petrochemically, and yet, it is completely biodegradable by aerobic/anaerobic biological processes to carbon dioxide, water, methane, and biomass. It should be noted that the concepts of biological and green should not be confused with "sustainable" biocomposites, which take into account not only one or two aspects, but the whole life cycle of the composite, from cradle to grave [129].

The biocomposite development process could involve the use of biotechnological methods to replace the non-renewable resources, using low-impact manufacturing chemicals and methods, and utilizing waste and recycled content to contribute to circularity. According to this definition, a sustainable biocomposite could be one that contains at least one naturally derived ingredient, and the overall impact of the biocomposite throughout its journey from production to consumption is considered positive without interfering with the environment [129].

Sustainable industrial consumption has been at the core of the Sustainable Development Goals (SDGs). It clearly emphasizes resource efficiency, the minimization and potential use of waste, as well as the minimal use of hazardous substances, also the integration of environmental and social responsibility. 


\section{Materials and Methods}

This section describes the methodological approach and research methods used within this study (see Figure 6). The main research tasks are as follows:

- T1: To develop the cognitive model of main stakeholders and processes of the value chain of the sustainable industrial consumption of biocomposite materials;

- T2: To investigate the influence of the COVID-19 pandemic on the sustainable industrial consumption of biocomposite materials;

- T3: To substantiate the research based on the integration of economic, business management, and natural-science perspectives and justify the interdisciplinary conceptual basis for further research.

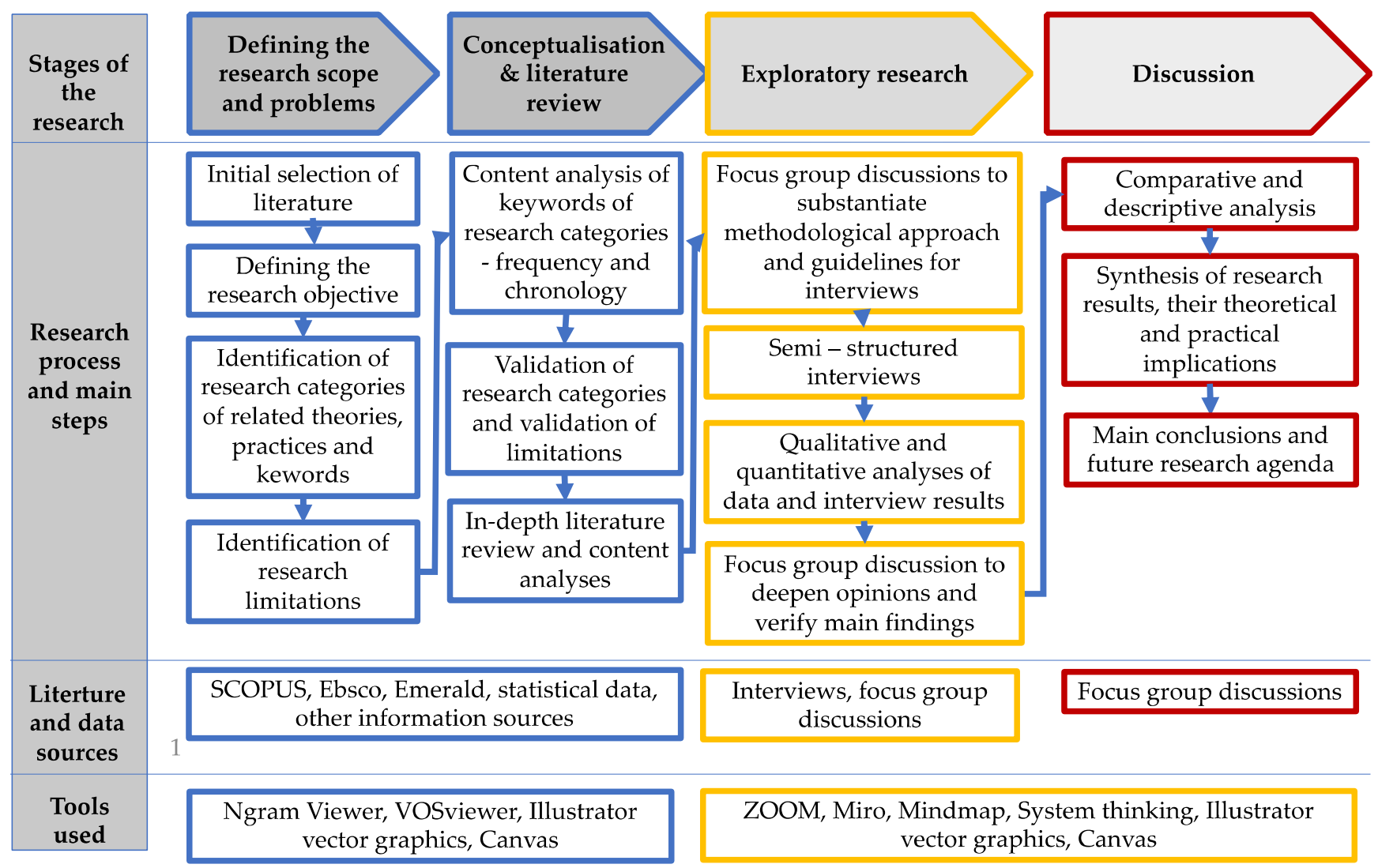

Figure 6. The methodological framework of this research (source: the authors).

The methodology of the research was based on the literature review, the content analysis of the literature, the focus group discussions, and expert semi-structured interviews. Using the descriptive analyses and the system thinking approach, the cognitive model of the process and main stakeholders of the sustainable consumption value chain has been visualized and described. The comparative analyses were applied to investigate empirical practices in the recent changes in the consumption patterns of industrial consumers.

To answer the research questions, the exploratory qualitative research was conducted, which helps to analyze the importance of biocomposite materials in sustainable industrial consumption and the impact of COVID-19.

The semi-structured interviews were conducted, transcribed, and classified. Semistructured interviews are commonly applied in the studies related to the sustainability and the circular economy $[30,130,131]$. The purposive sampling method [132] was used in the selection of informants for the interviews. In the beginning, a sample of informants was created based on the following criteria: (1) deep knowledge and expertise, (2) the comparatively high degree of involvement or engagement in the value chain, and (3) the position and the role in the process of the sustainable production of the biodegradable composite. 
In order to ensure reliability and competency in assessing and selecting potential informants, several focus group discussions were organized. Using the snowball sampling principles [133], during the interviews, informants were asked to suggest other important stakeholders or experts that should be included in the sample of interviews, thereby enriching the list of informants, based on the initial set of the criteria defined for the informants. In total, 10 interviews with an average duration of 60 to $120 \mathrm{~min}$ were conducted by phone or video calls (e.g., using zoom) were conducted (see Appendix A). All interviews were recorded for further data analyses and processing.

The selected sample of interviewees represented industrial actors related to the consumption of biodegradable composite materials. The interviewees were industry experts who had represented the industry on a long-term basis and could provide a comprehensive insight into it. These are both global and local companies representing the food, cosmetics, fashion, and furniture industries. All interviewees were related to the European market.

The structure of the questions of interviews is presented in Tables 2 and 3 . The interview questions consisted of two parts: (A) and (B). While part (A) revealed the general profile of the interviewee, part (B) collected opinions; the main research questions included such topics as EU Green Deal guidelines for industry, how consumer behavior affects industrial consumption during COVID-19, insights into the use of biocomposite materials at each stage of the value chain, and possible impacts of the COVID-19 pandemic.

Table 2. The structure of the questions of interviews-Part: A-Interviewee Profile.

\begin{tabular}{|c|c|c|}
\hline $\begin{array}{l}\text { Label } \\
\text { Codes }\end{array}$ & Questions & Types of Responses \\
\hline A-IQ1 & Represented sector/industry/field & Open \\
\hline A-IQ2 & Size of the company & Open: turnover in EUR \\
\hline A-IQ3 & Role in the sustainable production chain & $\begin{array}{l}\text { Closed: \#1 Feedstock production \& } \\
\text { pre-treatment; \#2 Raw material } \\
\text { processing and refining; \#3 Packaging } \\
\text { manufacturing, \#4 Product } \\
\text { manufacturing, \#4 Retailer }\end{array}$ \\
\hline A-IQ4 & Field of expertise/position & Open \\
\hline
\end{tabular}

The interview questions were piloted with several researchers before being given to our sample. The analyses of the interviews were performed in two stages. First, to ensure the validity and quality of data processing, the interviews were coded after being recorded and transcribed. After the coding, we proceeded with the data analyses through the detailed analyses of all questions by each interviewee and comparing the opinions of informants in each question discussed during the interview. The main results and conclusions of the analyses were synthesized.

This research has a particular focus on the industrial consumers of the value chain, excluding end consumer and waste management stages, specifying the limitations of this paper. Accordingly, the chosen methodology was adapted to assume these limitations and keep the focus of the research aim following methodological approaches kept by previous studies [134-138]. The literature analyses provides deeper insight into the nature and characteristics of concepts investigated. The exploratory research with semi-structured interviews and focus group discussions investigated the practice of companies regarding the sustainable industrial consumption and established the relationship of the potential impact of the COVID-19 pandemics.

This study was performed applying the multi-disciplinary approach by composing the expertise of the business management, engineering and material sciences, as well as the earth and environmental sciences. The lack of such multi-disciplinarity has been identified by previous research $[139,140]$, and this study addresses this research gap. This multi-disciplinary approach allowed the sustainable industrial consumption chain to be empirically analyzed in an in-depth and contextual way and to develop a conceptual model 
in order to reflect on the practices of the industrial sustainable consumption of biocomposite materials.

Table 3. The structure of the questions of interviews-Part: B-Main questions.

\begin{tabular}{|c|c|c|}
\hline Label Codes & Questions & Types of Responses \\
\hline B-IQ1 & $\begin{array}{l}\text { The general perception of the EU Green Deal Strategy and } \\
\text { the sustainability goals within the industry }\end{array}$ & Open \\
\hline B-IQ2 & $\begin{array}{l}\text { The general perception of the sustainability principles within } \\
\text { the company of the interviewee and its value chain }\end{array}$ & Open \\
\hline B-IQ3 & $\begin{array}{l}\text { The adoption/introduction of the sustainability principles } \\
\text { into the practice of the company of the interviewee and its } \\
\text { value chain }\end{array}$ & Open \\
\hline B-IQ4 & $\begin{array}{l}\text { If and how consumer behavior affects industrial } \\
\text { consumption during COVID-19 }\end{array}$ & Open \\
\hline B-IQ5 & $\begin{array}{l}\text { The general intention and the practice regarding the use of } \\
\text { biocomposite materials }\end{array}$ & Open \\
\hline B-IQ6 & $\begin{array}{l}\text { The opinion about the functionality, technological feasibility, } \\
\text { environmental, and economic aspects of the sustainable } \\
\text { packaging and, particularly, the use of biocomposite } \\
\text { materials }\end{array}$ & Open \\
\hline B-IQ7 & $\begin{array}{l}\text { Any changes observed within the use of biocomposite } \\
\text { materials during COVID-19 }\end{array}$ & Open \\
\hline B-IQ8 & $\begin{array}{l}\text { Possible impact of COVID-19 on the use of biocomposite } \\
\text { materials at each stage of the value chain (stages: \#1 } \\
\text { Feedstock production \& pre-treatment; \#2 Raw material } \\
\text { processing and refining; \#3 Packaging manufacturing; \#4 } \\
\text { Product manufacturing, \#4 Retailer) }\end{array}$ & $\begin{array}{l}\text { Closed: Positive, } \\
\text { neutral, negative }\end{array}$ \\
\hline
\end{tabular}

\section{Results}

The interview results reveal that the impact of external forces such as a change of consumer values, pro-environmental regulations, technologies, and new risks would require industrial consumers and packaging manufacturers to focus more on the use of raw materials and biocomposites. Recently, the food, cosmetics, and clothing sectors have been facing increasing importance of the problem regarding packaging sustainability. This is causing a growing interest in the use of biocomposites. Suppliers and processors of raw materials are forced to review, optimize, and adapt production processes in the direction of sustainable transition. It is important for industrial consumers to be fully aware of, and for the manufacturers to be able to justify, the origin of the raw materials. Such an assumption is supported by plans to introduce a declaration of origin (DoO) for products in the coming years. The participating stakeholders in a supply chain will be held responsible for arranging the respective flow of information, ensuring that every raw material is substantiated by a DoO. This will be facilitated by implementing strict requirements and regulations by the governing organizations.

The insights gathered from expert interviews have been used to develop the conceptual model for estimating the influence of COVID-19 on each stage of the value chain of sustainable industrial consumption of biocomposites (see Figure 7). The results show positive impact (green arrows in Figure 7) for the first three stages of the value chain, neutral impact for the Product manufacturing stage, and negative impact for the Retail stage. More details on these impacts are described in the following paragraphs. 


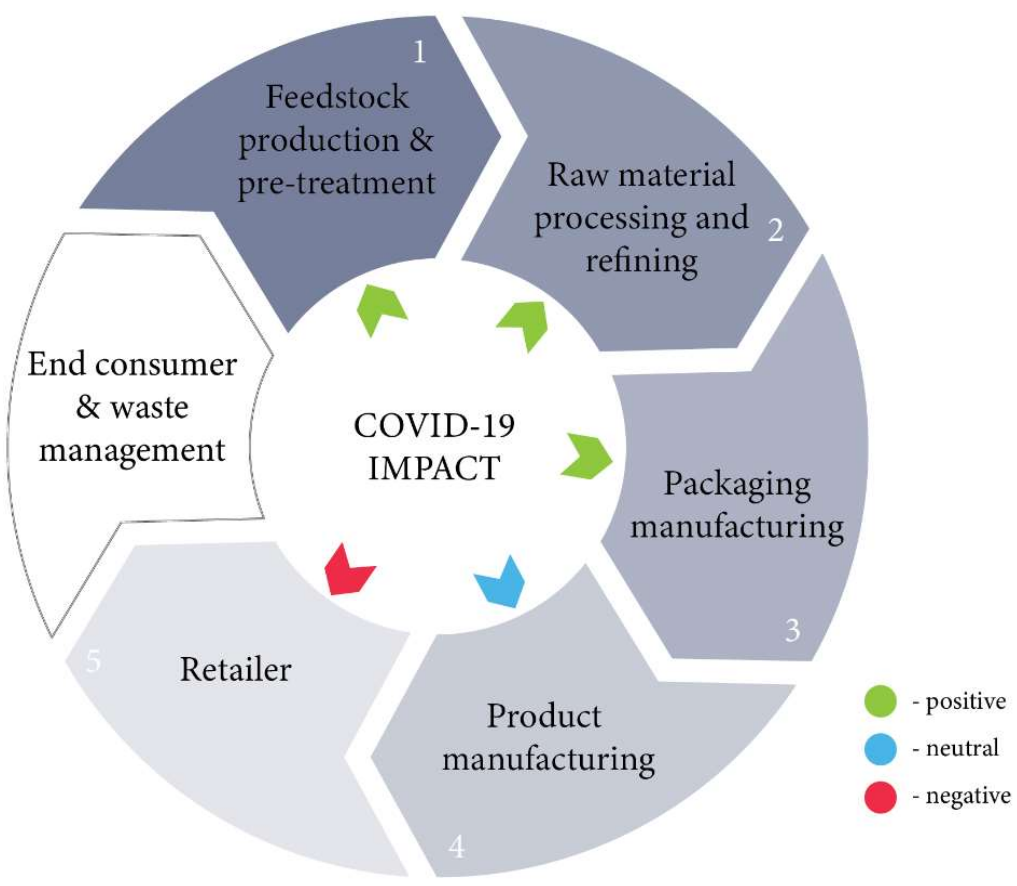

Figure 7. Conceptual model estimating the impact of the COVID-19 pandemic on the use of biocomposite materials within each stage of the value chain (source: the authors).

\subsection{Feedstock Production and Pre-Treatment}

Conclusions from the interviews reveal that the impact of COVID-19 on this stage of the value chain is generally positive. There is a growing interest in high-quality natural fiber raw materials and the use of hemp by-products. Experts have confirmed that hemp-based packaging has potential since no major material producer has introduced hemp-based packaging so far. Hemp producers would support the provision of hemp as a feedstock to be utilized for hemp packaging production purposes.

Feedstock production industry representatives reflect that the capacity to grow hemp in the Baltic states would be sufficient given that the relevant price is paid by the manufacturers or raw material buyers. In addition, it would be more advantageous, and the final fiber price would be better if both fiber and spools were sold.

An automotive industry expert indicated that there are already several car manufacturers, such as Tesla, who are developing saloon interior components that are made of composite materials, which include hemp. New solutions for integrating biocomposite materials into automotive engineering are also being developed; however, they are likely to be available on the market in several years.

\subsection{Raw Material Processing and Refining}

Overall, the impact of COVID-19 has not been negative due to increased demand for consumer products, while the introduction of new component product lines has been delayed.

Due to the continuity of production processes during COVID-19, the employees of the conversion and formulation units (manufacturing and technical staff) have been working as usual, while the employees of the R\&D department worked remotely. Therefore, the development and introduction of new products to the market was delayed and took longer than previously.

The consumption of organic and plant products has grown very rapidly over the past year; for example, the German market has grown by about $20 \%$ (it was $6-8 \%$ in previous years), and the Scandinavian market has grown by $30-40 \%$. It has been pointed out that this is a huge challenge for supply chains and a risk for suppliers of organic raw materials, as there are companies that are starting to replace growing demand with imported organic 
raw materials. However, it is becoming increasingly important for the consumers that the product is locally sourced and otherwise organic rather than using organic imports.

"Maybe in some extent, we are much prepared for pandemic time and new customer trends-healthy, natural, and with traceable or local materials than other entrepreneurs that are currently dependent on limited supplies of specific materials"

(an interviewee-I8)

\subsection{Packaging Manufacturers}

The responses reveal that the impact of COVID-19 at this stage of the value chain is generally positive and the interest in packaging made from biocomposites is growing.

Representatives of the food packaging industry pointed out that in the context of climate change, the public increasingly wants to see manufacturing companies doing business in a sustainable way that does not harm the environment. When it comes to health, safety, and the environment, food packaging manufacturers, along with end consumers, are keen to take control if chemical companies really practice what they preach and correspondingly can attest to the credibility of their communications.

Cosmetics packaging manufacturers indicated that brands selling natural cosmetics also prefer environmentally friendly packaging. On the other hand, the cosmetics (end product) manufacturing trends are currently focused on simplicity-fewer ingredients, concentrated composition, addressing a specific problem.

The cosmetics packaging manufacturing industry is also considered to be less sensitive to the price of packaging. Packaging manufacturers understand that it is important to offer a quality product and also relevant packaging that delivers on what has been promised to the end customer. At the same time, the cosmetics packaging industry is very complex-as technical and complex as food packaging manufacturing.

The demand for biodegradable packaging in the cosmetics industry is huge. Currently, all cosmetics manufacturers are looking for packaging solutions that are recyclable or alternative materials that do not contain microplastics. If the packaging is biodegradable, impermeable, and does not contain microplastics, there will be huge market demand for such packaging.

Conventional flexible plastic packaging is a rapidly growing segment, yet historically, less than $4 \%$ of flexible packaging is recycled. Flexible plastics are the leading polluting source to the oceans, with a minimum of $5 \mathrm{M}$ tons (of $11 \mathrm{M}$ ) being disposed of each year into the sea.

The overall results of the interviews show that there is rapidly growing interest from product manufacturers toward biodegradable packaging, especially over the recent years.

\subsection{Product Manufacturers}

The impact of COVID-19 has been evaluated as neutral by product manufacturers. Informants of the interviews confirm that entrepreneurs following the sustainability shift continue this development direction also during COVID-19.

"We continue to work with eco and sustainability issues as we did it before. It may take 3 or 4 years from the idea of the new product to the production and sales requiring more time than prior to COVID-19"

(an interviewee- $\mathrm{I} 5$ )

Packaging is considered to be an important sales tool by product manufacturers and the first opportunity to educate the consumer. For instance, the type of packaging for eco products is being selected by cosmetics manufacturers based on brand values and the requirements of the ECOCERT standards for eco-cosmetics.

This implies that only recyclable plastics or materials that decompose relatively quickly may be used. Cosmetics manufacturers choose the packaging according to the design and feeling that occurs when using the product packaging. The packaging must be convenient and easy to use. For instance, it is important that customers hear a nice click when the 
button is pushed and that the lipstick cases have a magnet. Product manufacturers confirm that the price of packaging is not the most important aspect. Instead, the composition of the packaging and its compatibility with the product is first assessed. At least several samples are tested before the right product packaging is selected, as one needs to make sure that the packaging meets all the manufacturing and end-user requirements. Manufacturers also evaluate the life cycle of the packaging including the process of obtaining raw materials and select the material that is the most environmentally friendly.

\subsection{Retailers}

The impact of COVID-19 has been evaluated as negative by retailers. Remote work and lockdowns in various countries have caused considerably bigger demand for e-commerce and online shopping, which in turn has caused higher demand for additional packaging that is required for shipping purposes to secure products from damage in transit. Thus, the negative impact is due to the increasing costs that retailers are required to cover for extra materials on packaging in comparison to the traditional in-store shopping requiring less packaging.

Since supply chains in the coming years will have the task of arranging the flow of information to substantiate the use of any raw material by a declaration, it is likely that it will be increasingly important for the retailers to justify the origin of the packaging materials, as this will be determined by strict regulations in the future.

Circular economy strategies are advancing faster than ever before because it is likely to become mandatory for retailers and other value chain members in the upcoming 10 years. For instance, for the furniture retail sector, the sustainability elements and requirements to be met are already included in part of the product profiles. In addition to the introduction of sustainability aspects in furniture production, companies are already actively abandoning disposable plastics for retail space, and only recyclable plastics are available in stores.

\section{Discussion and Conclusions}

The study found that the pandemic has left a positive impact on feed-stock producers, raw material producers, and packaging manufacturers due to an increase in online shopping that requires additional packaging, while product manufacturers felt no major impact. However, a negative impact has been left on retailers that experience increasing sales over online sales channels that correlate with a shipment of goods with courier delivery requiring additional packaging in comparison to the traditional in-store consumption.

Those companies that had previously taken the approach of the gradual transition toward the sustainability principles and the use of biodegradable materials are now continuing this process at an even faster pace and are generally a step further. That means that other value chain members will have to adjust respective internal processes and change, as this will be determined by the requirements of international regulations. For companies that have already started this sustainability shift and developed a sustainable strategy for the company several years ahead, the transition will be easier.

The use of the biocomposite materials within the sustainable value chain has mostly been related to the choices to adapt and introduce sustainable packaging. Based on previous efforts of researchers $[98,100]$ and professional organizations in defining the criteria of the sustainable packaging, the following matrix (see Table 4) has been proposed by this study, which integrates the functional, technologically feasible, environmental, and economic dimensions with the criteria of the sustainable packaging [97] and the sustainable supply chain [33]. For the successful promotion of the sustainable value chain and thus, in general, cleaner production, it is important to balance all four dimensions [141].

The analyses (Table 4) show which of the four dimensions are more explicitly influenced by each of the sustainable consumption criteria, thus indicating the dominant areas for managerial decisions to evaluate packaging options and opportunities for more sustainable supply chains. These dimensions highlight four directions of the implications and contributions to be addressed to managers and owners of businesses, practitioners 
or experts, policymakers, and other stakeholders. The environmental dimension is explicitly dominant and is strongly followed by the economic dimension. Pournader with co-authors [33] argue that the economic issues are the major drivers impacting managerial decisions, but environmental and sustainability issues are becoming important and bringing larger opportunities within the sustainable supply chain. Meanwhile, the functionality and technological feasibility plays a lesser role in the industrial consumption within the supply chain. The current technological advancement allows to reduce the importance of these issues in the strategic decision-making of managers, but these issues still are relevant for individual consumers and product end-users in the B2C consumption.

Table 4. Matrix of criteria and dimensions of the sustainable packaging.

\begin{tabular}{|c|c|c|c|c|}
\hline \multirow{2}{*}{$\begin{array}{l}\text { Criteria for Sustainable } \\
\text { Packaging }\end{array}$} & \multicolumn{4}{|c|}{ Dimensions of Sustainable Packaging } \\
\hline & Functional & $\begin{array}{l}\text { Technologically } \\
\text { Feasible }\end{array}$ & Environmental & Economic \\
\hline $\begin{array}{c}\text { 1. Safe and healthy for all } \\
\text { individuals throughout their life } \\
\text { cycle }\end{array}$ & $X$ & & $X$ & $X$ \\
\hline $\begin{array}{l}\text { 2. Meets market criteria in terms of } \\
\text { its performance and costs }\end{array}$ & & & & $X$ \\
\hline $\begin{array}{l}\text { 3. Obtained, produced, transported, } \\
\text { and processed using renewable } \\
\text { energy }\end{array}$ & & $X$ & $X$ & $X$ \\
\hline $\begin{array}{l}\text { 4. Produced using renewable or } \\
\text { recycled raw materials and clean } \\
\text { production technologies }\end{array}$ & & $X$ & $X$ & $X$ \\
\hline $\begin{array}{l}\text { 5. Made of harmless materials in all } \\
\text { possible end-of-life scenarios }\end{array}$ & $X$ & & $X$ & \\
\hline $\begin{array}{l}\text { 6. Physically designed and } \\
\text { validated to optimize used } \\
\text { materials and energy consumption }\end{array}$ & & $X$ & $X$ & $X$ \\
\hline $\begin{array}{l}\text { 7. Fully recovered and utilized in } \\
\text { industrial and/or biological } \\
\text { cradle-to-cradle cycles }\end{array}$ & $x$ & & $X$ & \\
\hline
\end{tabular}

It is essential for the development of a sustainable value chain to identify and map various stakeholders to acknowledge those who can positively contribute to the development of sustainability principles within the industrial consumption as well as identify those stakeholders who will be positively or negatively affected [83]. This will allow for a more comprehensive planning and design of sustainable business activities to meet the interests and needs of various stakeholders and the involvement of the most engaged stakeholders within balancing economic and environmental values, and developing the sustainable value chain.

Dangelico et al. [142] believe that with the growing number of green products in the market or green branding strategies, companies far more than ever before should acknowledge the concept of sustainable industrial consumption, sustainable packaging and, in general, the green behavior of consumers.

The Europe Commission released key data on the behavior of consumers in 2020. Some of the main findings were that $56 \%$ of consumers said environmental concerns influenced their purchasing decisions and $67 \%$ said that they bought products that were better for the environment, even if such products were more expensive. From this, we can conclude that these could be one of the main signals influencing industrial consumption trends [10].

The growing demand for the use of natural resources in the manufacture of biocomposites reflects the need for the circular economy for biocomposites while allowing them to be recycled and reused. It is noted that the development of biocomposite materials must be integrated into a circular economy model to ensure environmentally friendly and sustainable production. Such a conclusion supports the findings of the current research and the value chain member aims to achieve sustainable manufacturing processes [114].

The interest of industries in using biopolymers is also fueled by the sharp rise in the price of fossil-based raw materials (PP, HDPE, etc.) in recent months, as shown in Figure 8. 


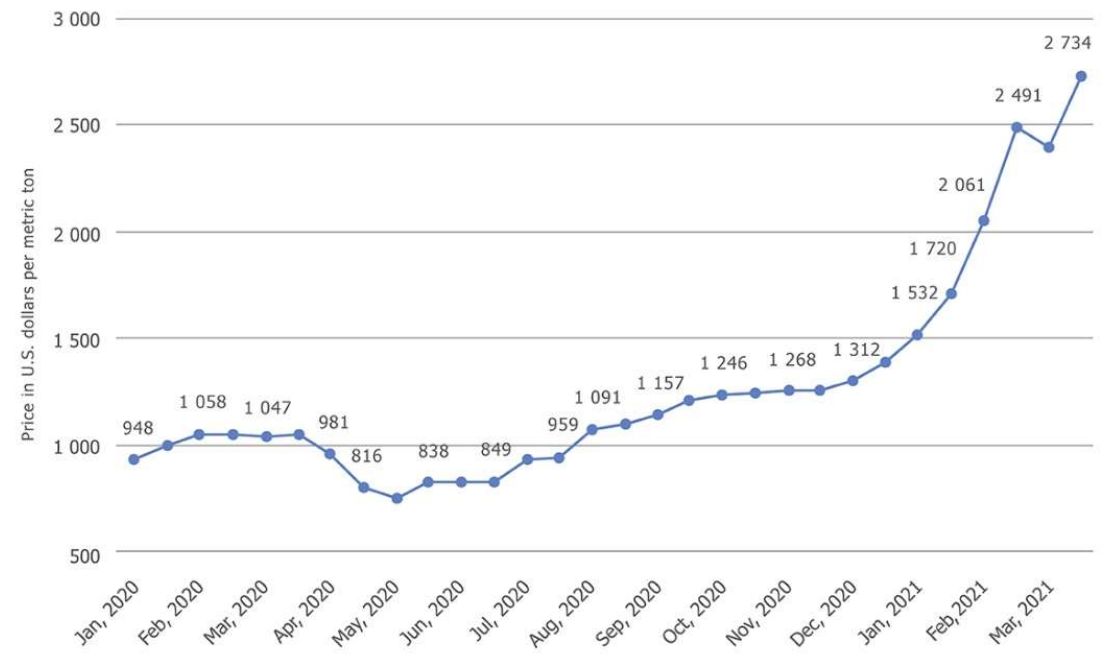

Figure 8. Global price increase in polypropylene (PP) from January 2020 to March 2021 (source: the authors based on [143]).

During the pathway toward sustainable materials use within industrial consumption, it is essential to recognize and address existing barriers and challenges. Researchers [144,145] have identified the main groups of barriers that currently hinder the development of sustainable value chains: among them, the insufficient critical mass of the production of sustainable plastics, relatively low demand for sustainable materials, lack of the economic justification and the technological feasibility for the development of recycling in this area, the comparatively high production costs, as well as a lack of proper technical and functional features, such as thermal instability as well as high oxygen and water vapor permeability. These are further issues relevant for both the academic society in planning future research directions with, for instance, the action research and experimentation methods aiming at the demonstration of practices and proving the feasibility and viability of the use of biocomposite materials. In addition, the desirability of industries to adopt new practices in using the biocomposite materials is essential and needs to be promoted, which is highly dependent on the technological possibilities and the economic interests of stakeholders. Researchers [144] have proposed various solutions that should help in this transition, including the following: (1) changing the general business mindset from the "firm-centric" or solo-preneurship practice to collaboration; (2) competing not with the price of products but the value proposition of the sustainability benefits and the general green nature of products; (3) reorganizing material flows and smart material solutions; and (4) companies sharing assets and developing common infrastructure instead of solely developing their own technologies.

The conceptual model developed above will require cross-functional coordination and collaboration. The COVID-19 pandemic has significantly strengthened the digital capacity of different sectors [146]. These lessons learned and newly obtained digital capacities should be used for the adoption of digital technologies throughout the value chain encouraging innovations as well as more efficient and smart use of materials.

The COVID-19 pandemic has reduced various business activities and general consumption, leading to decrease in emissions; however, this progress is more due to the slowdown in economic growth [147]. The COVID-19 pandemic has created or exacerbated a number of consumption trends that business representatives should acknowledge and escalate in the future, including health, sustainability, the circular economy [145]. The adoption of these trends are outstanding issue within the packaging and in the supply chain as a whole.

Climate-neutral packaging and the product as a whole are expected to receive increasing attention in the near future not only for marketing purposes but also to improve their competitiveness and reduce the cost of the natural resource tax. It is important to 
pay attention to the promotion of innovative industrial processes and the development of new technologies as soon as possible in order to stimulate the wider adoption and use of biocomposite materials [148].

The likely implications on business and policy and consumer trends are related to the need for the higher transparency and traceability of each process including the value chain of the sustainable consumption of renewable and biodegradable composite materials. For example, this could manifest as growing expectations between B2B suppliers and customers for the traceability of the material and product origin, increasing the public discussion of end customers in social networks and online media by retail customers regarding the use of specific materials and their origin. This is also likely to be the subject of research in the near future. In this context, the discussion on different aspects related to greenwashing should take place more often.

It is important for both smaller and larger companies now to think a step forward, implement a sustainability strategy, plan LCA in the development of new products, and thereby improve their competitiveness in the future.

The companies willing to move toward the sustainable industrial chain will have to incorporate economic, environmental, social, stakeholder, volunteer, resilience, and long-term directions within their strategies. The importance of all these issues and the necessity to adopt them is crucial in any organization belonging to the sustainable value chain $[83,89]$.

Within such grand challenges as the COVID-19 pandemic, social issues related to general resilience first become crucial, which affects also industrial consumption. Yet, this study and the interviews of experts confirm the need to pay more attention to environmental issues in order to ensure the well-being of the earth and natural capital. Otherwise, the progress achieved within sustainable development will regress backwards with negative effects. Positively, those actors acknowledging the sustainable values and implementing the sustainability principles into their logistics, purchases, supplies, and other processes need to continue and even reinforce this path during such grand challenges as the COVID-19 pandemic. In turn, this is a signal to policymakers to strengthen the financial and nonfinancial support for the identification and implementation of sustainability principles in the supply chain of industrial customers and the total value chain of the B2B segment.

This research contributes to the theory and practice regarding the enablers and challenges for the use of biocomposites in the further transformation toward more sustainable consumption. This study highlights the research gaps that still need to be investigated regarding the impact of COVID-19 on the sustainable consumption of end consumers and their changing behaviors that confront the traditional less sustainable practices of industrial consumers.

In the coming years, the topic will not only be about how to rebuild the economy after the impact of COVID-19 but also how to make it more sustainable. At present, cross-sectoral cooperation and a willingness to help industrial companies understand environmental, social responsibility, and governance standards are particularly important.

The development of the sustainable value chain is largely linked to investments in ecoinnovations and the environmentally friendly technologies that are especially important in industrial regions neglecting sustainability challenges [149]. In this regard, government support at national, regional, and local levels is essential to strengthen the values of sustainable consumption and environmentally friendly production by creating a greater critical mass of the sustainable value chains within the industrial consumption and economic relationships.

Possible future research directions and current gaps identified after implementation of the research include but are not limited to the following:

- The role of waste recycling policy in facilitating sustainable industrial consumption.

- More detailed investigations of hindering factors of the introduction of biocomposites and recycling, in particular, related to the economic interests of stakeholders and technological factors. 
- Promoting the competitiveness of sustainable industrial consumption partners by eliminating greenwashing.

- Difficulties in the introduction of biocomposites in the industry and overcoming them.

- The impact of the actualization of microplastic pollution problems on the production of non-degradable bioplastics.

- The end of the life cycle of conventional plastics after recycling, when they have lost their properties for further use.

- Industrial consumer difficulties within the EU green transition.

Author Contributions: D.R.: Conceptualization, Methodology, Analyses, Investigation, Data curation, Visualization, Writing - original draft. A.S.: Conceptualization, Methodology, Investigation, Data curation, Visualization, Writing — original draft. I.U.: Conceptualization, Methodology, Analyses, Investigation, Visualization, Data Curation, Validation, Writing-original draft and editing, Supervision. J.B.: Conceptualization, Methodology, Investigation, Validation, Writing—original draft, review and editing. D.A.: Conceptualization, Methodology, Formal Analyses, Validation, Writing—original draft, review and editing, Supervision, Funding acquisition, Resources. I.M.: Writing-review and editing, Supervision, Project administration, Funding acquisition, Resources. All authors have read and agreed to the published version of the manuscript.

Funding: This research was funded by the Latvian Council of Science, the project "The Impact of COVID-19 on Sustainable Consumption Behaviors and Circular Economy (Funding/Grant No. lzp-2020/2-0317)".

Institutional Review Board Statement: Not applicable.

Informed Consent Statement: Not applicable.

Data Availability Statement: Data available upon request.

Conflicts of Interest: The authors declare no conflict of interest. The funders had no role in the design of the study; in the collection, analyses, or interpretation of data; in the writing of the manuscript, or in the decision to publish the results.

\section{Appendix A}

Table A1. Characteristics of the Interviewees.

\begin{tabular}{|c|c|c|c|c|c|c|}
\hline No & $\begin{array}{l}\text { Field of Expertise of } \\
\text { Interviewee }\end{array}$ & $\begin{array}{l}\text { Role in the } \\
\text { Sustainable } \\
\text { Production Chain }\end{array}$ & $\begin{array}{l}\text { Industry or Field of the } \\
\text { Operation of the } \\
\text { Organization Represented } \\
\text { (Part of the Value Chain) }\end{array}$ & $\begin{array}{l}\text { Size of the } \\
\text { Company } \\
\text { (Turnover EUR in } \\
\text { 2020) }\end{array}$ & $\begin{array}{l}\text { Duration of } \\
\text { Interview }\end{array}$ & $\begin{array}{c}\text { The Time Period of } \\
\text { the Interview }\end{array}$ \\
\hline $\mathrm{I} 1$ & $\begin{array}{l}\text { Corporate Social } \\
\text { Responsibility, } \\
\text { Sustainability }\end{array}$ & Retailer (BE) & FMCG Retail & 36 bn & $1 \mathrm{~h}$ & 2nd quarter of 2021 \\
\hline $\mathrm{I} 2$ & Country Manager & Retailer (LV, LT) & $\begin{array}{c}\text { Furniture Manufacturing } \\
\text { and Retail }\end{array}$ & $39 \mathrm{bn}$ & $60 \mathrm{~min}$ & 3rd quarter of 2020 \\
\hline I3 & $\begin{array}{l}\text { Head of Store } \\
\text { Development } \\
\text { Department }\end{array}$ & Retailer (IT) & Clothing Retail & $17 \mathrm{bn}$ & $90 \mathrm{~min}$ & 3rd quarter of 2020 \\
\hline $\mathrm{I} 4$ & $\begin{array}{c}\text { Manufacturing, Lead } \\
\text { of R\&D }\end{array}$ & $\begin{array}{c}\text { Product } \\
\text { manufacturer (LV) }\end{array}$ & Cosmetics & $16 \mathrm{M}$ & $60 \mathrm{~min}$ & 3rd quarter of 2020 \\
\hline $\mathrm{I} 5$ & General Manager & $\begin{array}{c}\text { Product } \\
\text { manufacturer (LV) }\end{array}$ & Food & $1 \mathrm{M}$ & $60 \mathrm{~min}$ & 2nd quarter of 2021 \\
\hline I6 & $\begin{array}{l}\text { Regional Head of } \\
\text { R\&D }\end{array}$ & $\begin{array}{c}\text { Packaging } \\
\text { manufacturer (DE) }\end{array}$ & $\begin{array}{l}\text { Cosmetics, Consumer } \\
\text { Goods }\end{array}$ & $102 \mathrm{M}$ & $120 \mathrm{~min}$ & 3rd quarter of 2020 \\
\hline I7 & Head of R\&D & $\begin{array}{c}\text { Packaging } \\
\text { manufacturer (IL) }\end{array}$ & Food & & $60 \mathrm{~min}$ & 2nd quarter of 2021 \\
\hline I8 & $\mathrm{CEO}$ & Raw material (SE) & Starch Producer & $1 \mathrm{M}$ & $60 \mathrm{~min}$ & 2nd quarter of 2021 \\
\hline I9 & CEO & Raw material (DE) & Fiber Producer & $1 \mathrm{M}$ & $60 \mathrm{~min}$ & 2nd quarter of 2021 \\
\hline $\mathrm{I} 10$ & Board Member & Feedstock (LV) & Hemp Raw Materials & & $60 \mathrm{~min}$ & 2nd quarter of 2021 \\
\hline
\end{tabular}




\section{References}

1. United Nations. The Sustainable Development Goals Report 2021. New York: United Nations.Halkos, G.; Gkampoura, E.-Ch.; 2021. Where do we stand on the 17 Sustainable Development Goals? An overview on progress. Econ. Anal. Policy 2021, 70, 94-122. [CrossRef]

2. Fischer, D.; Reinermann, J.L.; Guillen-Mandujano, G.; DesRoches, C.T.; Diddi, S.; Vergragt, P.J. Sustainable consumption communication: A review of an emerging field of research. J. Clean. Prod. 2021, 300, 126880. [CrossRef]

3. Kirchherr, J.; Piscicelli, L.; Bour, R.; Kostense-Smit, E.; Muller, J.; Huibrechtse-Truijens, A.; Hekkert, M. Barriers to the circular economy: Evidence from the European Union (EU). Ecol. Econ. 2018, 150, 264-272. [CrossRef]

4. Uvarova, I.; Atstaja, D.; Korpa, V. Challenges of the introduction of circular business models within rural SMEs of EU. Int. J. Econ. Sci. 2020, 9, 128-149. [CrossRef]

5. Kirchherr, J.; Reike, D.; Hekkert, M. Conceptualizing the circular economy: An analysis of 114 definitions. Resour. Conserv. Recycl. 2017, 127, 221-232. [CrossRef]

6. European Commission. Communication from the Commission to the European Parliament, the Council, the European Economic and Social Committee and the Committee of the Regions. The European Green Deal; European Commission: Brussels, Belgium, 2019.

7. European Circular Economy Stakeholder Platform. 2021. Available online: https:// circulareconomy.europa.eu/platform/en/ commitments/hm-groups-vision-become-100-circular (accessed on 20 July 2021).

8. Wróblewska-Krepsztul, J.; Rydzkowski, T.; Borowski, G.; Szczypiński, M.; Klepka, T.; Thakur, V.K. Recent progress in biodegradable polymers and nanocomposite-based packaging materials for sustainable environment. Int. J. Polym. Anal. Charact. 2018, 23, 383-395. [CrossRef]

9. Cohen, M.J. Does the COVID-19 outbreak mark the onset of a sustainable consumption transition? Sustain. Sci. Pract. Policy 2020, 16, 1-3. [CrossRef]

10. European Bioplastics. Bioplastics Market Development Update 2020. 2020. Available online: https:/ / docs.european-bioplastics org/conference/Report_Bioplastics_Market_Data_2020_short_version.pdf (accessed on 20 July 2021).

11. OECD. Business Models for the Circular Economy: Opportunities and Challenges from a Policy Perspective. In Recircle Resource Efficient \& Circular Economy Project; OECD Publishing: Paris, France, 2018.

12. Melnyk, S.A.; Handfield, R.B.; Catalogne, R.J. Integrating Environmental Concerns into the Design Process: The Gap between Theory and Practice. IEEE Trans. Eng. Manag. 2001, 48, 189-208.

13. Porter, M.E. America's green strategy. Sci. Am. 1991, 264, 168. [CrossRef]

14. Porter, M.E.; Van der Linde, C. Toward a New Conception of Environment-Competitiveness Relationship. J. Econ. Perspect. 1995, 9, 97-118. [CrossRef]

15. De Jesus, A.; Mendonça, S. Lost in transition? Drivers and barriers in the eco-innovation road to the circular economy. Ecol. Econ. 2018, 145, 75-89. [CrossRef]

16. Ranta, V.; Aarikka-Stenroos, L.; Mäkinen, S.J. Creating value in the circular economy: A structured multiple-case analysis of business models. J. Clin. Prod. 2018, 201, 988-1000. [CrossRef]

17. Potting, J.; Hekkert, M.P.; Worrell, E.; Hanemaaijer, A. Circular Economy: Measuring Innovation in the Product Chain; PBL Publishers: The Hague, The Netherlands, 2017.

18. Bocken, N.; van Bogaert, A. Sustainable business model innovation for positive societal and environmental impact. In Sustainable Development Research at ICIS: Taking Stock and Looking Ahead; ICIS; Maastricht University: Maastricht, Netherlands, 2016; pp. 107-119.

19. Funk, K. Sustainability and performance. MIT Sloan Manag. Rev. 2003, 44, 65-70.

20. Lo, S.F.; Sheu, H.J. Is corporate sustainability a value-increasing strategy for business? Corp. Gov. Int. Rev. 2007, 15, 345-358. [CrossRef]

21. Laufer, W.S. Social accountability and corporate greenwashing. J. Bus. Ethics 2003, 43, 253-261. [CrossRef]

22. Torelli, R.; Balluchi, F.; Lazzini, A. Greenwashing and environmental communication: Effects on stakeholder" perceptions. Bus. Strategy Environ. 2020, 29, 407-421. [CrossRef]

23. Nekmahmud, M.; Fekete-Farkas, M. Why not green marketing? Determinates of consumers' intention to green purchase decision in a new developing nation. Sustainability 2020, 12, 7880. [CrossRef]

24. Wang, Z.; Hsieh, T.S.; Sarkis, J. CSR performance and the readability of CSR reports: Too good to be true? Corp. Soc. Responsib. Environ. Manag. 2018, 25, 66-79. [CrossRef]

25. Walker, K.; Wan, F. The harm of symbolic actions and green-washing: Corporate actions and communications on environmental performance and their financial implications. J. Bus. Ethics 2012, 109, 227-242. [CrossRef]

26. Loučanová, E.; Šupín, M.; Čorejová, T.; Repková-Štofková, K.; Šupínová, M.; Štofková, Z.; Olšiaková, M. Sustainability and Branding: An Integrated Perspective of Eco-innovation and Brand. Sustainability 2021, 13, 732. [CrossRef]

27. Delmas, M.A.; Burbano, V.C. The drivers of greenwashing. Calif. Manag. Rev. 2011, 54, 64-87. [CrossRef]

28. Massaro, M.; Secinaro, S.; Dal Mas, F.; Brescia, V.; Calandra, D. Industry 4.0 and circular economy: An exploratory analysis of academic and practitioners' perspectives. Bus. Strategy Environ. 2021, 30, 1213-1231. [CrossRef]

29. Smol, M.; Kulczycka, J.; Avdiushchenko, A. Circular economy indicators in relation to eco-innovation in European regions. Clean Technol. Environ. Policy 2017, 19, 669-678. [CrossRef] 
30. Scarpellini, S. Social indicators for businesses' circular economy: Multi-faceted analysis of employment as an indicator for sustainability reporting. Eur. J. Soc. Impact Circ. Econ. 2021, 2, 17-44. [CrossRef]

31. Azwa, Z.N.; Yousif, B.F.; Manalo, A.C.; Karunasena, W. A review on the degradability of polymeric composites based on natural fibres. Mater. Des. 2013, 47, 424-442. [CrossRef]

32. Nordin, N.; Selke, S. Social aspect of sustainable packaging. Packag. Technol. Sci. 2010, 23, 317-326. [CrossRef]

33. Pournader, M.; Sauer, P.C.; Fahimnia, B.; Seuring, S. Behavioral studies in sustainable supply chain management. Int. J. Prod. Econ. 2022, 243, 108344. [CrossRef]

34. Uvarova, I.; Mavlutova, I.; Atstaja, D. Development of the green entrepreneurial mindset through modern entrepreneurship education. IOP Conf. Ser. Earth Environ. Sci. 2020, 628, 012034. [CrossRef]

35. Dwivedi, A.; Agrawal, D.; Jha, A.; Gastaldi, M.; Paul, S.K.; D’Adamo, I. Addressing the challenges to sustainable initiatives in value chain flexibility: Implications for Sustainable Development Goals. Glob. J. Flex. Syst. Manag. 2021, 22, 179-197. [CrossRef]

36. Kamble, S.S.; Gunasekaran, A.; Gawankar, S.A. Sustainable Industry 4.0 framework: A systematic literature review identifying the current trends and future perspectives. Process Saf. Environ. Prot. 2018, 117, 408-425. [CrossRef]

37. Seuring, S.; Müller, M. From a literature review to a conceptual framework for sustainable supply chain management. J. Clean. Prod. 2008, 16, 1699-1710. [CrossRef]

38. Ibn-Mohammed, T.; Mustapha, K.B.; Godsell, J.M.; Adamu, Z.; Babatunde, K.A.; Akintade, D.D.; Koh, S.C.L. A critical review of the impacts of COVID-19 on the global economy and ecosystems and opportunities for circular economy strategies. Resour. Conserv. Recycl. 2020, 164, 105169. [CrossRef]

39. Belmonte-Ureña, L.J.; Plaza-Úbeda, J.A.; Vazquez-Brust, D.; Yakovleva, N. Circular economy, degrowth and green growth as pathways for research on sustainable development goals: A global analysis and future agenda. Ecol. Econ. 2021, 185, 107050. [CrossRef]

40. Fratila, D. 8.09-Environmentally friendly manufacturing processes in the context of transition to sustainable production". Compr. Mater. Process. 2014, 8, 163-175.

41. Pereira, C.J. Environmentally friendly processes. Chem. Eng. Sci. 1999, 54, 1959-1973. [CrossRef]

42. Jawahir, I.S.; Wanigarathne, P.C.; Wang, X. Product design and manufacturing processes for sustainability. In Chapter 12Mechanical Engineers' Handbook; John Wiley and Sons: Hoboken, NJ, USA, 2006; pp. 414-443.

43. Brunner, P.H.; Rechberger, H. Handbook of Material Flow Analysis: For Environmental, Resource, and Waste Engineers; CRC Press: Boca Raton, FL, USA, 2016. [CrossRef]

44. Laner, D.; Rechberger, H.; Astrup, T. Systematic evaluation of uncertainty in material flow analysis. J. Ind. Ecol. 2014, 18, 859-870. [CrossRef]

45. Ilgin, M.A.; Gupta, S.M. Environmentally conscious manufacturing and product recovery (ECMPRO): A review of the state of the art. J. Environ. Manag. 2010, 91, 563-591. [CrossRef] [PubMed]

46. Delmas, M.A.; Pekovic, S. Resource efficiency strategies and market conditions. Long Range Plan. 2015, 48, 80-94. [CrossRef]

47. Thiede, S.; Bogdanski, G.; Herrmann, C. A systematic method for increasing the energy and resource efficiency in manufacturing companies. Procedia CIRP 2012, 2, 28-33. [CrossRef]

48. Rennings, K.; Christian, R. Increasing Energy and Resource Efficiency through Innovation: An Explorative Analysis Using Innovation Survey Data. 2009. Available online: https:/ / madoc.bib.uni-mannheim.de/2479/ (accessed on 30 June 2021).

49. Nakamura, S.; Kondo, Y. Input-output analysis of waste management. J. Ind. Ecol. 2002, 6, 39-63. [CrossRef]

50. Finnveden, G.; Hauschild, M.Z.; Ekvall, T.; Guinée, J.; Heijungs, R.; Hellweg, S.; Koehler, A.; Pennington, D.; Suh, S. Recent developments in life cycle assessment. J. Environ. Manag. 2009, 91, 1-21. [CrossRef]

51. Oliveira, C.; Coelho, D.; Antunes, C.H. Coupling input-output analysis with multiobjective linear programming models for the study of economy-energy-environment-social (E3S) trade-offs: A review. Ann. Oper. Res. 2016, 247, 471-502. [CrossRef]

52. Minx, J.C.; Wiedmann, T.; Wood, R.; Peters, G.P.; Lenzen, M.; Owen, A.; Scott, K.; Barrett, J.; Hubacek, K.; Baiocchi, G.; et al Input-output analysis and carbon footprinting: An overview of applications. Econ. Syst. Res. 2009, 21, 187-216. [CrossRef]

53. Di Maio, F.; Rem, P.C.; Baldé, K.; Polder, M. Measuring resource efficiency and circular economy: A market value approach. Resour. Conserv. Recycl. 2017, 122, 163-171. [CrossRef]

54. Evans, S.; Vladimirova, D.; Holgado, M.; Van Fossen, K.; Yang, M.; Silva, E.A.; Barlow, C.Y. Business model innovation for sustainability: Towards a unified perspective for creation of sustainable business models. Bus. Strategy Environ. 2017, 26, 597-608. [CrossRef]

55. Veleva, V.; Ellenbecker, M. Indicators of sustainable production: Framework and methodology. J. Clin. Prod. 2001, 9, 519-549. [CrossRef]

56. Bocken, N.M.; Geradts, T.H. Barriers and drivers to sustainable business model innovation: Organization design and dynamic capabilities. Long Range Plan. 2020, 53, 101950. [CrossRef]

57. Veleva, V.; Bodkin, G. Corporate-entrepreneur collaborations to advance a circular economy. J. Clin. Prod. 2018, 188, 20-37. [CrossRef]

58. Bocken, N.; Boons, F.; Baldassarre, B. Sustainable business model experimentation by understanding ecologies of business models. J. Clin. Prod. 2019, 208, 1498-1512. [CrossRef]

59. Konietzko, J.; Bocken, N.; Hultink, E.J. Circular ecosystem innovation: An initial set of principles. J. Clin. Prod. 2020, $253,119942$. [CrossRef] 
60. Brown, P.; Baldassarre, B.; Konietzko, J.; Bocken, N.; Balkenende, R. A tool for collaborative circular proposition design. J. Clin. Prod. 2021, 297, 126354. [CrossRef]

61. Uvarova, I.; Platonova, I.; Rascevska, Z.; Volkova, T.; Atstaja, D. The value co-creation in circular business models: Quadruplex Helix perspective. In Proceedings of the 6th International Conference on New Business Models: New Business Models in a Decade of Action: Sustainable, Evidence-based, Impactful, Halmstad, Sweden, 9-11 June 2021; pp. 382-389, ISBN 978-91-88749-68-0.

62. Lüdeke-Freund, F.; Carroux, S.; Joyce, A.; Massa, L.; Breuer, H. The sustainable business model pattern taxonomy-45 patterns to support sustainability-oriented business model innovation. Sustain. Prod. Consum. 2018, 15, 145-162. [CrossRef]

63. Geissdoerfer, M.; Vladimirova, D.; Evans, S. Sustainable business model innovation: A review. J. Clin. Prod. 2018, 198, 401-416. [CrossRef]

64. Bocken, N.M.; Short, S.W.; Rana, P.; Evans, S. A literature and practice review to develop sustainable business model archetypes. J. Clin. Prod. 2014, 65, 42-56. [CrossRef]

65. Young, W.; Hwang, K.; McDonald, S.; Oates, C.J. Sustainable consumption: Green consumer behaviour when purchasing products. Sustain. Dev. 2010, 18, 20-31. [CrossRef]

66. Hargreaves, T. Practice-ing behaviour change: Applying social practice theory to pro-environmental behaviour change. J. Consum. Cult. 2011, 11, 79-99. [CrossRef]

67. Tukker, A.; Tischner, U. Product-services as a research field: Past, present and future. Reflections from a decade of research. $J$. Clin. Prod. 2006, 14, 1552-1556. [CrossRef]

68. Mont, O. Institutionalisation of sustainable consumption patterns based on shared use. Ecol. Econ. 2004, 50, 135-153. [CrossRef]

69. Mavlutova, I.; Kuzmina, J.; Uvarova, I.; Atstaja, D.; Lesinskis, K.; Mikelsone, E.; Brizga, J. Does Car Sharing Contribute to Urban Sustainability from User-Motivation Perspectives? Sustainability 2021, 13, 10588. [CrossRef]

70. Armstrong, C.M.J. Fashion and the Buddha: What Buddhist Economics and Mindfulness Have to Offer Sustainable Consumption. Cloth. Text. Res. J. 2021, 39, 91-105. [CrossRef]

71. Dimante, D.; Tambovceva, T.; Atstaja, D. Raising environmental awareness through education. Int. J. Contin. Eng. Educ. Life-Long Learn. 2016, 26, 259-272. [CrossRef]

72. Henry, M.; Schraven, D.; Bocken, N.; Frenken, K.; Hekkert, M.; Kirchherr, J. The battle of the buzzwords: A comparative review of the circular economy and the sharing economy concepts. Environ. Innov. Soc. Transit. 2021, 38, 1-21. [CrossRef]

73. Wang, P.; McCarthy, B.; Kapetanaki, A.B. To be ethical or to be good? The impact of 'Good Provider' and moral norms on food waste decisions in two countries. Glob. Environ. Change 2021, 69, 102300. [CrossRef]

74. Armstrong, C.M.; Niinimäki, K.; Kujala, S.; Karell, E.; Lang, C. Sustainable product-service systems for clothing: Exploring consumer perceptions of consumption alternatives in Finland. J. Clin. Prod. 2015, 97, 30-39. [CrossRef]

75. Reijonen, H.; Bellman, S.; Murphy, J.; Kokkonen, H. Factors related to recycling plastic packaging in Finland's new waste management scheme. Waste Manag. 2021, 131, 88-97. [CrossRef] [PubMed]

76. Tanner, C.; Kast, W.S. Promoting sustainable consumption: Determinants of green purchases by Swiss consumers. Psychol. Mark. 2003, 20, 883-902. [CrossRef]

77. Ahir, R.K.; Chakraborty, B. A meta-analytic approach for determining the success factors for energy conservation. Energy 2021, 230, 120821. [CrossRef]

78. De las Heras, A.; Relinque-Medina, F.; Zamora-Polo, F.; Luque-Sendra, A. Analysis of the evolution of the sharing economy towards sustainability. Trends and transformations of the concept. J. Clin. Prod. 2020, 291, 125227. [CrossRef]

79. Costa, N.; Patrício, L.; Morelli, N.; Magee, C.L. Bringing service design to manufacturing companies: Integrating PSS and service design approaches. Des. Stud. 2018, 55, 112-145. [CrossRef]

80. Fuentes, C.; Cegrell, O.; Vesterinen, J. Digitally enabling sustainable food shopping: App glitches, practice conflicts, and digital failure. J. Retail. Consum. Serv. 2021, 61, 102546. [CrossRef]

81. Porter, M. Competitive Advantage: Creating and Sustaining Superior Performance; Free Press: New York, NY, USA, 1985.

82. Koval, V.; Duginets, G.; Plekhanova, O.; Antonov, A.; Petrova, M. On the supranational and national level of global value chain management. Entrep. Sustain. Issues 2019, 6, 1922. [CrossRef]

83. Nasr, A.K.; Kashan, M.K.; Maleki, A.; Jafari, N.; Hashemi, H. Assessment of barriers to renewable energy development using stakeholders approach. Entrep. Sustain. Issues 2020, 7, 2526. [CrossRef]

84. Koberg, E.; Longoni, A. A systematic review of sustainable supply chain management in global supply chains. J. Clin. Prod. 2019, 207, 1084-1098. [CrossRef]

85. Beske, P.; Land, A.; Seuring, S. Sustainable supply chain management practices and dynamic capabilities in the food industry: A critical analysis of the literature. Int. J. Prod. Econ. 2014, 152, 131-143. [CrossRef]

86. Seuring, S. A review of modeling approaches for sustainable supply chain management. Decis. Support Syst. 2013, 54, 1513-1520. [CrossRef]

87. Costa, C.; Antonucci, F.; Pallottino, F.; Aguzzi, J.; Sarriá, D.; Menesatti, P. A Review on Agri-Food Supply Chain Traceability by Means of RFID Technology. Food Bioprocess Technol. 2013, 6, 353-366. [CrossRef]

88. Saberi, S.; Kouhizadeh, M.; Sarkis, J.; Shen, L. Blockchain technology and its relationships to sustainable supply chain management. Int. J. Prod. Res. 2019, 57, 2117-2135. [CrossRef]

89. Ahi, P.; Searcy, C. A comparative literature analysis of definitions for green and sustainable supply chain management. J. Clin. Prod. 2013, 52, 329-341. [CrossRef] 
90. Chumtong, J.; Kaldewey, D. Beyond the Google ngram viewer. Forum Internationale Wissenschaft. 2017. Available online: https: / / bonndoc.ulb.uni-bonn.de/xmlui / bitstream/handle/20.500.11811/1150/FIW_Working_Paper_08.pdf?sequence=1 (accessed on 30 June 2021).

91. Zimmermann, L.; Dombrowski, A.; Völker, C.; Wagner, M. Are bioplastics and plant-based materials safer than conventional plastics? In vitro toxicity and chemical composition. Environ. Int. 2020, 145, 106066. [CrossRef]

92. Raddadi, N.; Fava, F. Biodegradation of oil-based plastics in the environment: Existing knowledge and needs of research and innovation. Sci. Total Environ. 2019, 679, 148-158. [CrossRef]

93. Amulya, K.; Katakojwala, R.; Ramakrishna, S.; Mohan, S.V. Low carbon biodegradable polymer matrices for sustainable future. Compos. Part C Open Access 2021, 4, 100111. [CrossRef]

94. Babu, R.P.; O'Connor, K.; Seeram, R. Current progress on bio-based polymers and their future trends. Prog. Biomater. 2013, 2, 8. [CrossRef] [PubMed]

95. Iwata, T. Biodegradable and bio-based polymers: Future prospects of eco-friendly plastics. Angew. Chem. Int. Ed. 2015, 54, 3210-3215. [CrossRef]

96. SPC. Definition of Sustainable Packaging. Sustainable Packaging Coalition, A Project of Greenblue. 2011. Available online: https:/ / sustainablepackaging.org/wp-content/uploads/2017/09/Definition-of-Sustainable-Packaging.pdf (accessed on 24 July 2021).

97. Verghese, K.; Lewis, H.; Lockrey, S.; Williams, H. Packaging's role in minimizing food loss and waste across the supply chain. Packag. Technol. Sci. 2015, 28, 603-620. [CrossRef]

98. Wikström, F.; Williams, H.; Trischler, J.; Rowe, Z. The importance of packaging functions for food waste of different products in households. Sustainability 2019, 11, 2641. [CrossRef]

99. De Mello Soares, C.T.; Ek, M.; Östmark, E.; Gällstedt, M.; Karlsson, S. Recycling of multi-material multilayer plastic packaging: Current trends and future scenarios. Resour. Conserv. Recycl. 2022, 176, 105905. [CrossRef]

100. Boz, Z.; Korhonen, V.; Sand, C.K. Consumer considerations for the implementation of sustainable packaging: A review. Sustainability 2020, 12, 2192. [CrossRef]

101. Kolybaba, M.; Tabil, L.G.; Panigrahi, S.; Crerar, W.J.; Powell, T.; Wang, B. Biodegradable polymers: Past, present, and future. In $A S A B E / C S B E$ North Central Intersectional Meeting; American Society of Agricultural and Biological Engineers: Avenue North Fargo, ND, USA, 2006; p. 1.

102. Abu Ghalia, M.; Dahman, Y. Synthesis and utilization of 15 natural fibre-reinforced poly (lactic acid) bionanocomposites. In Lignocellulosic Fibre and Biomass-Based Composite Materials; Woodhead Publishing: Sawston, UK, 2017; pp. 313-345. [CrossRef]

103. Rai, P.; Mehrotra, S.; Priya, S.; Gnansounou, E.; Sharma, S.K. Recent advances in the sustainable design and applications of biodegradable polymers. Bioresour. Technol. 2021, 325, 124739. [CrossRef] [PubMed]

104. Meixner, O.; Katt, F. Assessing the impact of COVID-19 on consumer food safety perceptions-A choice-based willingness to pay study. Sustainability 2020, 12, 7270. [CrossRef]

105. Kitz, R.; Walker, T.; Charlebois, S.; Music, J. Food packaging during the COVID-19 pandemic: Consumer perceptions. Int. J. Consum. Stud. 2021. [CrossRef] [PubMed]

106. Siracusa, V.; Rocculi, P.; Romani, S.; Dalla Rosa, M. Biodegradable polymers for food packaging: A review. Trends Food Sci. Technol. 2008, 19, 634-643. [CrossRef]

107. Vikhareva, I.N.; Buylova, E.A.; Yarmuhametova, G.U.; Aminova, G.K.; Mazitova, A.K. An overview of the main trends in the creation of biodegradable polymer materials. J. Chem. 2021, 2021, 5099705. [CrossRef]

108. Righetti, M.C.; Cinelli, P.; Mallegni, N.; Stäbler, A.; Lazzeri, A. Thermal and mechanical properties of biocomposites made of poly (3-hydroxybutyrate-co-3-hydroxyvalerate) and potato pulp powder. Polymers 2019, 11, 308. [CrossRef] [PubMed]

109. Prajapati, S.K.; Jain, A.; Jain, A.; Jain, S. Biodegradable polymers and constructs: A novel approach in drug delivery. Eur. Polym. J. 2019, 120, 109191. [CrossRef]

110. George, A.; Shah, P.A.; Shrivastav, P.S. Natural biodegradable polymers based nano-formulations for drug delivery: A review. Int. J. Pharm. 2019, 561, 244-264. [CrossRef]

111. Cohn, D.; Zarek, M.; Elyashiv, A.; Sbitan, M.A.; Sharma, V.; Ramanujan, R.V. Remotely triggered morphing behavior of additively manufactured thermoset polymer-magnetic nanoparticle composite structures. Smart Mater. Struct. 2021, 30, 045022. [CrossRef]

112. Kumar, A.; Jyske, T.; Möttönen, V. Properties of injection molded biocomposites reinforced with wood particles of short-rotation aspen and willow. Polymers 2020, 12, 257. [CrossRef] [PubMed]

113. Girometta, C.; Picco, A.M.; Baiguera, R.M.; Dondi, D.; Babbini, S.; Cartabia, M.; Pellegrini, M.; Savino, E. Physico-mechanical and thermodynamic properties of mycelium-based biocomposites: A review. Sustainability 2019, 11, 281. [CrossRef]

114. Shanmugam, V.; Mensah, R.A.; Försth, M.; Sas, G.; Restás, Á.; Addy, C.; Xu, Q.; Jiang, L.; Neisiany, R.E.; Singha, S.; et al. Circular economy in biocomposite development: State-of-the-art, challenges and emerging trends. Compos. Part C Open Access 2021, 5, 100138. [CrossRef]

115. Joshi, S.V.; Drzal, L.T.; Mohanty, A.K.; Arora, S. Are natural fibre composites environmentally superior to glass fibre reinforced composites? Compos. Part A 2004, 35, 371-376. [CrossRef]

116. Sheldon, R.A.; Norton, M. Green chemistry and the plastic pollution challenge: Towards a circular economy. Green Chem. 2020, 22, 6310-6322. [CrossRef] 
117. Verma, D.; Gope, P.C.; Maheshwari, M.K.; Sharma, R.K. Bagasse fibre composites: A review. J. Mater. Environ. Sci. 2012, 3, 1079-1092.

118. Fuqua, M.A.; Huo, S.; Ulven, C.A. Natural fibre reinforced composites. Polym. Rev. 2012, 52, 259-320. [CrossRef]

119. Dungani, R.; Karina, M.; Subyakto; Sulaeman, A.; Hermawan, D.; Hadiyane, A. Agricultural waste fibres towards sustainability and advanced utilization: A review. Asian J. Plant Sci. 2016, 15, 42-55. [CrossRef]

120. Aigbodion, V.S. Bean pod ash nanoparticles a promising reinforcement for aluminium matrix biocomposites. J. Mater. Res. Technol. 2019, 8, 6011-6020. [CrossRef]

121. Gurunathan, T.; Mohanty, S.; Sanjay, K.; Nayak, S.K. A review of the recent developments in biocomposites based on natural fibres and their application perspectives. Compos. Part A 2015, 77, 1-25. [CrossRef]

122. Smoca, A.; Kukle, S.; Zelca, Z. Properties of hemp fibres reinforced PLA composites. Key Engineering Materials. Key Eng. Mater. 2019, 800, 205-209. [CrossRef]

123. Rafiee, K.; Schritt, H.; Pleissner, D.; Kaur, G.; Brar, S.K. Biodegradable green composites: It's never too late to mend. Curr. Opin. Green Sustain. Chem. 2021, 30, 100482. [CrossRef]

124. EIHA. Hemp a Real Green Deal. European Industrial Hemp Association. 2020. Available online: https://eiha.org/wp-content/ uploads/2020/09/Hemp-a-real-green-deal_EN.pdf (accessed on 25 July 2021).

125. Mohan, S.V.; Katakojwala, R. Circular Chemistry Conceptual Framework: A way forward to Sustainability in Industry 4.0. Curr. Opin. Green Sustain. Chem. 2020, 28, 100434. [CrossRef]

126. Kobayashi, T.; Nakajima, L. Sustainable development goals for advanced materials provided from industry wastes and biomass sources. Curr. Opin. Green Sustain. Chem. 2021, 28, 100439. [CrossRef]

127. Dicker, M.P.; Duckworth, P.F.; Baker, A.B.; Francois, G.; Hazzard, M.K.; Weaver, P.M. Green composites: A review of material attributes and complementary applications. Compos. Part A Appl. Sci. Manuf. 2014, 56, 280-289. [CrossRef]

128. Chemat, F.; Vian, M.A.; Ravi, H.K. Towards petroleum-free with plant-based chemistry. Curr. Opin. Green Sustain. Chem. 2021, 28, 100450. [CrossRef]

129. Chang, B.P.; Mohanty, A.K.; Misra, M. Studies on durability of sustainable biobased composites: A review. RSC Adv. 2020, 10, 17955-17999. [CrossRef]

130. Uddin, M.J. How the agent-based banking model might facilitate financial inclusion and sustainability via economic circularity?-A Bangladesh perspective. Eur. J. Soc. Impact Circ. Econ. 2020, 1, 76-94. [CrossRef]

131. Geng, Y.; Zhu, Q.; Doberstein, B.; Fujita, T. Implementing China's circular economy concept at the regional level: A review of progress in Dalian, China. Waste Manag. 2009, 29, 996-1002. [CrossRef]

132. Tongco, M.D.C. Purposive sampling as a tool for informant selection. Ethnobot. Res. Appl. 2007, 5, 147-158. [CrossRef]

133. Biernacki, P.; Waldorf, D. Snowball sampling: Problems and techniques of chain referral sampling. Sociol. Methods Res. 1981, 10, 141-163. [CrossRef]

134. Salzmann, O.; Ionescu-Somers, A.; Steger, U. The business case for corporate sustainability: Literature review and research options. Eur. Manag. J. 2005, 23, 27-36. [CrossRef]

135. Merli, R.; Preziosi, M.; Acampora, A. How do scholars approach the circular economy? A systematic literature review. J. Clean. Prod. 2018, 178, 703-722. [CrossRef]

136. Dal Mas, F.; Massaro, M.; Lombardi, R.; Garlatti, A. From output to outcome measures in the public sector: A structured literature review. Int. J. Organ. Anal. 2019, 27, 1631-1656. [CrossRef]

137. Alhawari, O.; Awan, U.; Bhutta, M.K.S.; Ülkü, M.A. Insights from circular economy literature: A review of extant definitions and unravelling paths to future research. Sustainability 2021, 13, 859. [CrossRef]

138. Vurro, C.; Russo, A.; Perrini, F. Shaping sustainable value chains: Network determinants of supply chain governance models. J. Bus. Ethics 2009, 90, 607-621. [CrossRef]

139. Durán-Romero, G.; López, A.M.; Beliaeva, T.; Ferasso, M.; Garonne, C.; Jones, P. Bridging the gap between circular economy and climate change mitigation policies through eco-innovations and Quintuple Helix Model. Technol. Forecast. Soc. Chang. 2020, 160, 120246. [CrossRef]

140. Scarpellini, S.; Marín-Vinuesa, L.M.; Aranda-Usón, A.; Portillo-Tarragona, P. Dynamic capabilities and environmental accounting for the circular economy in businesses. Sustain. Accounting, Manag. Policy J. 2020, 11, 1129-1158. [CrossRef]

141. Radavičius, T.; van der Heide, A.; Palitzsch, W.; Rommens, T.; Denafas, J.; Tvaronavičienè, M. Circular solar industry supply chain through product technological design changes. Insights Reg. Dev. 2021, 3, 10-30. [CrossRef]

142. Dangelico, R.M.; Nonino, F.; Pompei, A. Which are the determinants of green purchase behaviour? A study of Italian consumers. Bus. Strategy Environ. 2021, 30, 2600-2620. [CrossRef]

143. Global Price Increase of Polypropylene (PP) from January 2020 to March 2021. Available online: https://www.statista.com/ statistics/1239058/bi-monthly-polypropylene-price-worldwide/ (accessed on 25 July 2021).

144. Siltaloppi, J.; Jähi, M. Toward a sustainable plastics value chain: Core conundrums and emerging solution mechanisms for a systemic transition. J. Clean. Prod. 2021, 315, 128113. [CrossRef]

145. Barone, A.S.; Matheus, J.R.V.; de Souza, T.S.P.; Moreira, R.F.A.; Fai, A.E.C. Green-based active packaging: Opportunities beyond COVID-19, food applications, and perspectives in circular economy-A brief review. Compr. Rev. Food Sci. Food Saf. 2021, 20, 4881-4905. [CrossRef] 
146. Zhao, L.; Kim, K. Responding to the COVID-19 Pandemic: Practices and strategies of the global clothing and Textile value chain. Cloth. Text. Res. J. 2021, 39, 157-172. [CrossRef]

147. Koval, V.; Olczak, P.; Vdovenko, N.; Boiko, O.; Matuszewska, D.; Mikhno, I. Ecosystem of environmentally sustainable municipal infrastructure in the Ukraine. Sustainability 2021, 13, 10223. [CrossRef]

148. Stankevičius, A.; Novikovas, A.; Bakaveckas, A.; Petryshyn, O. EU waste regulation in the context of the circular economy: Peculiarities of interaction. Entrep. Sustain. Issues 2020, 8, 533-545. [CrossRef]

149. Koval, V.; Mikhno, I.; Udovychenko, I.; Gordiichuk, Y.; Kalina, I. Sustainable natural resource management to ensure strategic environmental development. TEM J. 2021, 10, 1022-1030. [CrossRef] 